\title{
Private equity and human capital risk
}

\author{
Manfred Antoni ${ }^{\mathrm{a}}$, Ernst Maug ${ }^{\mathrm{b}, *}$, Stefan Obernberger ${ }^{\mathrm{c}}$ \\ a Institute for Employment Research (IAB), Regensburger Str. 100, Nuremberg 90478, Germany \\ ${ }^{\mathrm{b}}$ University of Mannheim, L9 1-2, Mannheim 68131, Germany \\ ${ }^{\mathrm{c}}$ Erasmus University Rotterdam, Burgemeester Oudlaan 50, Rotterdam 3000DR, The Netherlands
}

\section{A R T I C L E I N F O}

\section{Article history:}

Received 27 July 2017

Revised 7 August 2018

Accepted 9 October 2018

Available online 25 April 2019

\section{JEL classification:}

G30

G34

J24

J31

M51

Keywords:

Private equity

Restructuring

Human capital risk

Buyouts

Wages

\begin{abstract}
A B S T R A C T
We study the human capital effects of private equity buyouts in Germany. We conduct matched-sample difference-in-differences estimations at the establishment and at the individual employee level with more than 152 thousand buyout employees and a carefully matched control group. Buyouts are followed by a reduction in overall employment and an increase in employee turnover. Employees of buyout targets experience earnings declines equivalent to $2.8 \%$ of median earnings in the fifth year after the buyout. Managers and older employees fare far worse after buyouts compared with the average target employee, even though they are not more likely to lose their jobs at the target compared with other employees. We argue that the employees most negatively affected after buyouts are those who are less likely to find new employment, not those who are most likely to lose their jobs. Evidence exists of a reduction in administrative staff and more hiring for jobs that require IT skills.
\end{abstract}

(c) 2019 The Authors. Published by Elsevier B.V. This is an open access article under the CC BY-NC-ND license. (http://creativecommons.org/licenses/by-nc-nd/4.0/)

\footnotetext{
W We thank Ingolf Dittmann, Rainer Haselmann, Christoph Schneider, Peter Severin, Joacim Tåg, Vadym Volosovych, Dong Yan, and seminar participants at Bocconi University, Cass Business School, Chinese University of Hong Kong, Cyprus University of Technology, Erasmus University Rotterdam, University of St. Gallen, University of Mannheim, University of New South Wales, Tel Aviv University, ESSEC Corporate Governance Conference, European Finance Association meetings, German Finance Association meetings, Fifth Annual Corporate Finance Conference at Lancaster University, and the First International FDZ Data User Workshop in Michigan. Nora Pankratz, Franziska Manke, and Simon Tatomir provided valuable research assistance. We are grateful to Jürgen Egeln and Johannes Bersch at the Center of European Economic Research in Mannheim for providing us with access to their Creditreform data, to Markus Janser (IAB) for providing us with access to the digital-tools index, to Bundesverband Deutscher Kapitalbeteiligungsgesellschaften (BVK) for buyout data, and to Heiko Stüber (IAB) for worker flow data. This research was funded by the German Research Foundation (DFG) under grants BE 3172/1-1 , HE 7171/2-1, and MA 3317/3-1.

* Corresponding author.

E-mail address: maug@uni-mannheim.de (E. Maug).
}

\section{Introduction}

In this paper, we analyze the human capital risk associated with private equity (PE) buyouts in Germany. ${ }^{1}$ The social costs associated with private equity restructuring have been the subject of emotional debates. The head of the German Social Democratic Party once compared buyout firms with "swarms of locusts" who "descend on companies, graze, and then move on," suggesting that private equity firms make short-term profits by imposing large costs

\footnotetext{
${ }^{1}$ The literature conventionally refers to leveraged buyouts (LBOs), whereas our study is on private equity buyouts (PE buyouts). We discuss this distinction in Section 2.1 .
} 
on employees. ${ }^{2}$ Discussions in other countries created similar sentiments. ${ }^{3}$

The literature in finance and economics has conventionally regarded private equity buyouts as vehicles for improving firms' governance and operating performance, facilitating growth and creative destruction, and, more recently, modernizing firms' technology. ${ }^{4}$ From this modernization perspective, private equity buyouts create value by fashioning leaner firms and enhancing growth through organizational, operational, and technological improvements. Critics argue that shareholders gain in private equity buyouts at the expense of other stakeholders, in particular, the government through lower taxes, and employees. This transfer-of-wealth view echoes the critical stance articulated in the public debate. Shleifer and Summers (1988) provide a theoretical foundation for this view and suggest that investor-led restructurings do not create value but simply transfer wealth from employees and other stakeholders to shareholders by reneging on implicit contracts.

We contribute to this debate by analyzing 511 private equity buyouts in Germany between 2002 and 2008. Germany is fairly representative for the Organisation for Economic Co-operation and Development (OECD) regarding employment protection legislation (EPL), making it a well-suited laboratory for studying this matter. ${ }^{5}$ We perform matched-sample difference-in-differences analyses at the establishment level and the individual level. We first match each target establishment to multiple control establishments and then we match each target employee to another employee from one of the matching control establishments. Matching at both levels is performed based on a rich set of establishment, job, and employee characteristics. We conduct analyses at the establishment level and the individual level over a five-year period after the buyout.

We ask two questions: How do job growth, separations, and hiring at the establishment level develop after buyouts? Are buyouts associated with human capital risk for the employees of target firms? We ask both questions

\footnotetext{
2 See Bild am Sonntag, April 17, 2005 (see also http://de.wikipedia.org/ wiki/Heuschreckendebatte).

3 Davis et al. (2014) cite a closely related argument by then prime minister of Denmark Poul Rasmussen (see Wong, 2007). The same arguments about private equity firms were rehearsed again in the 2012 US presidential campaign when Democratic politicians chastised Republican candidate Mitt Romney for his career at Bain Capital, blaming him for socially irresponsible restructuring methods. See Weisberg (2012). The International Trade Union Confederation made similar statements (ITUC, 2007).

4 The following papers articulate these views, for operating performance: Jensen (1989) and Kaplan and Stromberg (2009); for facilitating growth: Boucly et al. (2011); for catalyzing creative destruction: Davis et al. (2014); and for modernizing technology: Agrawal and Tambe (2016) and Olsson and Tåg (2017).

5 Our assessment is based on the EPL index published by Allard (2005) and constructed by the OECD, which was also used by Simintzi et al. (2014). In 2003, the last year reported by Allard (2005) and the second year of our sample, Germany ranks 12th in terms of the strictness of employment protection among 21 OECD countries with an index value of 2.1 , which is also the mean. Other countries with studies on the employment implications of buyouts include the US (index value: 0.6 ; rank 21), the UK (index value: 1.4; rank: 15), and Sweden (index value: 2.7 ; rank: 5).
}

for all employees in our sample and for groups of employees who could be particularly vulnerable to or who could benefit from restructuring. The two questions we ask are related but distinct. PE firms may increase employee turnover without reducing overall establishment-level employment, and some of the employees who are replaced and lose their jobs with the target perhaps do not find new employment. We find this to be the case for older workers, who lose their jobs at target establishments at almost exactly the same rate as younger workers but experience significantly larger losses of long-term employment and wages. Hence, it is important to distinguish firm-level decisions and individual outcomes, because some groups, e.g., low-paid workers, seem to find new employment easily, whereas others, such as older workers, often remain unemployed.

Buyout establishments reduce their employment by 8.96\% more compared with the control group in the period up to five years after the buyout. This effect can be decomposed into an increase in the separation rate of $18.75 \%$ and an increase in the hiring rate of $9.79 \%$. About half of the increase in departures from buyout targets results in replacements and the other half in job destruction. The investigation of deal-level growth, separation, and hiring rates shows a strong and positive correlation between hiring rates and separation rates and almost half of the buyouts are followed by a period of increased employee turnover. Moreover, we often find higher separation rates and higher hiring rates for the same groups of employees. Private equity firms restructure firms by reducing employment and by replacing employees. In our sample, they employ both strategies at about the same rate. The increase in hiring is largely concentrated in the first years after the buyout, whereas most of the separations happen in later years. We may observe separations later because buyout firms want to increase profitability toward the end of their investment horizon to achieve better sales prices. Alternatively, the evaluation of targets' operations and the implementation of restructuring strategies could simply take time. We find, at the individual level, a downward trend in employee earnings after private equity buyouts. The average buyout target employee loses $€ 980$ in annual earnings after five years compared with the matched control group, which is $2.8 \%$ of median earnings in our sample.

The individual-level analyses identify three groups of employees whose post-buyout losses are significantly larger than those of the average buyout employee: whitecollar workers, managers, and older employees. Our discussion of employee groups is guided by three sets of explanations of buyout-related changes in employment and wages: (1) organizational streamlining, (2) technological modernization, and (3) transfers of wealth. We begin with organizational streamlining, i.e., the notion that buyout investors reduce administrative staff and layers of management. White-collar workers experience higher separation rates with less replacement in the short term and significantly higher losses of employment and earnings compared with other employees, consistent with the notion that buyout investors streamline firms by reducing administrative staff. For managers, we find very strong results at the individual level, but not at the establishment level, 
which suggests that buyout firms do not systematically reduce layers of middle management. We thus attribute the adverse development for managers to their difficulties in finding new employment, not the human resource policies of buyout investors.

Next, we turn to the argument that buyouts foster technological modernization. Private equity firms can implement new technologies, either because target managers resist change or because private equity investors have additional technological expertise. As a result, buyout targets can undergo faster technological modernization than control firms. We are careful to distinguish different notions of technological change, each of which has specific and sometimes different implications for employees. Proponents of the skill-biased technological change (SBTC) hypothesis (Katz and Autor, 1999; Autor et al., 2003) argue that technological change is biased against lower-skilled jobs and increases wage inequality. Separation rates for low-wage workers are almost twice as high as those for the sample as a whole. They are not displaced by those with higher wage levels, but by other low-wage employees. The net rate of job growth for low-wage workers is not unusually low, whereas turnover is unusually high. Individual-level results even show that low-wage employees lose less after buyouts than other employees, suggesting that skill-biased technological change does not determine individual outcomes.

According to a more recent version of the technologicalmodernization argument, medium-skilled workers could lose out toward either high-skilled or low-skilled workers through the displacement of routine jobs as a result of investments in information technology and robots (routinization) or through the reorganization of supply chains and trade (offshoring). We investigate these hypotheses at the individual and at the establishment level by looking at a range of technology-related job and employee classifications and find no evidence to support these hypotheses in our sample. Closely related is the argument that technological trends favor groups who have skills complementary to new technologies, such as information technology (IT) skills. We find some evidence that employment in jobs that require stronger IT skills increases in the first two years after buyouts. ${ }^{6}$

Finally, we investigate if buyouts involve a transfer of wealth in which the new owners gain at the expense of buyout target employees. We distinguish two versions of the transfer-of-wealth argument, both of which rely on implicit-contract theory. The first version holds that optimal risk-sharing between employees and firms involves that firms offer employees employment insurance (e.g., Azariadis, 1975) and that dynamic wage profiles rise over time, providing quasi-rents for older workers (Harris and Holmstrom, 1982), which buyout investors can appropriate. The second version holds that new owners benefit at the expense of employees by taking advantage of employees' lock-in from firm-specific human capital. The separation rates between older and younger employees do not differ,

\footnotetext{
${ }^{6}$ See Autor et al. (2003) and Autor and Dorn (2013). On buyouts, see Agrawal and Tambe (2016) and Olsson and Tåg (2017).
}

and the separation rates for employees with higher tenure, our measure of firm-specific human capital, are lower than those for employees with lower tenure. Hence, we find no support for either version of the transfer-of-wealth argument from these as well as other analyses. The finding on tenure is better explained by insider-outsider theories that postulate the entrenchment of insiders and more job security for employees with a longer tenure on their jobs (Lindbeck and Snower, 1986; Lindbeck and Snower, 1988). Nonetheless, we show a large long-term decline in earnings for older employees, the only group for which we observe a significantly negative effect on daily wages. These observations suggest that older employees suffer from the increase in employee turnover because they are less successful in finding new employment and sometimes have to accept employment for lower pay.

Several theories we investigate, in particular, explanations related to organizational streamlining and technological change, build on the notion that buyout investors change the composition of the workforce of buyout targets. Apart from the observations on white-collar workers and jobs with IT requirements, no support exists for explanations related to the composition of the workforce. Instead, we find declining employment and increased employee turnover for most groups of employees, which is broadly consistent with the modernization perspective on private equity buyouts. Increased turnover has long-term negative consequences for those employees who have more difficulty finding new employment, probably because the new owners after the buyout identify lower-ability employees and their departures from the buyout target provide a negative signal to the labor market.

Prior work on the human capital consequences of buyouts studies employment and wage effects mostly at the firm level or at the establishment level. ${ }^{7}$ Three recent contributions are close to ours in terms of data and methodology. Davis et al. (2014) are unique in combining firm-level and establishment-level analyses. All other papers focus on only one level of analysis. Our analysis complements theirs by combining individual- and establishment-level analyses. Two contributions to the buyout literature are based on individual-level data. Olsson and Tåg (2017) analyze individual-level employment data for private equity buyouts in Sweden. They find strong evidence for labor market polarization, which contrasts with our results, most likely because the economic environment and labor market regulation in Sweden are different from that in Germany. Agrawal and Tambe (2016) use an individual-level data set obtained from an online job-search platform in the US. They argue that buyouts increase IT-related investments, which enhance workers' human capital and increase firms' likelihood of survival. We differ from Agrawal and Tambe (2016) in terms of methodology, data sources, and results. Our analysis includes a broader set of variables and covers aspects of modernization other than IT-related invest-

\footnotetext{
7 A non-exhaustive list of papers on the employment consequences of buyouts is Kaplan (1989), Lichtenberg and Siegel (1990), Wright et al. (1992), Amess and Wright (2007), and Boucly et al. (2011). The surveys by Kaplan and Stromberg (2009), Wright et al. (2009), and Eckbo and Thorburn (2013) list additional contributions.
} 
ments. By relying on an online job-search platform, their analysis perhaps does not reflect the negative impact of buyouts on workers who do not use such platforms.

Our paper also contributes to the larger literature on finance and labor, which is too large to present and discuss here. We contribute to the part of the finance and labor literature that investigates how corporate finance decisions and events affect employees. Other parts of this literature investigate the implications of mergers and acquisitions (Tate and Yang, 2016; Lee et al., 2018), bankruptcies (Brown and Matsa, 2016; Graham et al., 2013), and capital structure choices (Matsa, 2010; Agrawal and Matsa, 2013). The buyout context differs from mergers and acquisitions, as it does not involve a reallocation of employees between acquirer and target, and from bankruptcies, as the buyouts in our sample do not seem to be in financial difficulties. We do not analyze leverage. The two studies on capital structure analyze questions entirely different from ours.

The following Section describes our data set and the matching methodology. Section 3 presents establishmentlevel and individual-level analyses for the whole sample. Section 4 analyzes groups of employees and Section 5 concludes.

\section{Data and methodology}

In this section, we describe the construction of the sample (Section 2.1), the matching process (Section 2.2), and descriptive statistics (Section 2.3).

\subsection{Sample construction}

The analysis requires linking three separate data sets: a data set containing private equity backed majority acquisitions, a data set on establishments (Establishment History Panel, BHP, see Schmucker et al., 2016), and a data set containing the employment history of individuals (Integrated Employment Biographies, IEB). The administrative establishment and employment history data are provided by the Institute for Employment Research (IAB) in Nuremberg, Germany. The IAB data are not organized in terms of legal units such as companies, but in terms of establishments, defined by their physical location.

We collect data on 891 German private equity buyouts for the period 2002-2008 by integrating into one data set the transactions reported in Thomson One and Capital IQ and a proprietary data set of the Bundesverband für Kapitalanlagegeselleschaften (BVK). We include all deals in which a private equity investor acquires a majority stake in a firm. In the following, we use the terms "private equity buyout," "PE buyout," or just "buyout." The data set starts in 2002, because coverage of PE buyouts for earlier years is very low in all three databases. We exclude secondary buyouts as well as transactions after 2008, because we want to observe the performance over the subsequent five years, and individual employment history data are available only until 2013. This leaves 798 transactions. Table OA1 in the Online Appendix provides an overview of the steps involved in constructing the sample.

We collect the subsidiary structure of buyout targets provided by Hoppenstedt's Firmendatenbank. The IAB then employs record linkage techniques (for details, see the Appendix) to link parent companies and majority-owned subsidiaries to their establishments in the BHP. After this step, we are left with 544 transactions and 2,652 establishments. For those 544 transactions, we select all employees for whom we have sufficient information on all control or matching variables on both the employee and the establishment level over the 11-year period we require. Our employee data come from the IEB. For an overview on all control and matching variables, see Table 1 and Table OA2 in the Online Appendix. The IEB contain detailed longitudinal data on almost the entire German workforce. We provide details on the sources of the IEB and our data preparation in Section A.2 of the Appendix. Next, we delete all transactions for which we find fewer than ten employees, because companies with fewer than ten employees enjoy privileges in terms of labor protection laws. Excluding these deals is inconsequential for our results. These steps leave 513 transactions, 2,563 establishments, and 208,449 employees. In the final step, we construct matched samples on both the establishment level and the individual level. We eventually end up with 511 transactions, 2,420 target establishments, and 152,057 target employees.

We collect some additional information on target firms. This information is limited, because disclosure regulation for private firms was not enforced before 2007 and standard financial data are not available for most of our target firms for most of our sample period. Therefore, we match the target firms to data that were collected by Creditreform, a company specialized on debt collection, and provided to us by the Centre for European Economic Research (ZEW). We can match close to half of our sample and provide the results in Table OA3 in the Online Appendix. Creditreform provides credit scores in four levels from "very good" to "very critical," and 216 , or $93 \%$ percent of firms for which credit scores are available, have a credit score of "good" or "very good." Creditreform asks companies about their business outlook and rates business outlooks on a scale with 12 verbal descriptions, which we aggregate into five scores from best ("expanding") to worst ("declining"). Only 15 or $6.4 \%$ of the 233 companies for which data were available in the event year described their business outlook as "declining" or "stagnating" in the event year; 42 (18\%) did not respond to this question. Based on their credit ratings and descriptions of their business outlook, most target companies appear to be financially healthy. Only about $6 \%$ to $7 \%$ of the firms for which we have data seem to be declining or in a critical situation.

German labor regulation provides employees with significant representation on the supervisory boards of corporations. Corporations with more than five hundred employees in Germany are required to have at least one-third of the members of the supervisory board elected by employees. For firms with more than two thousand employees, half of the seats of the supervisory board are reserved for employee representatives. The firms in our sample are mostly below these thresholds. Hiring and separation rates of establishments do not differ depending on the level of employee representation on the board, and we do not follow up on this categorization. (See Table OA4 in the Online Appendix.) 
Table 1

Description of variables.

The table describes all numerical variables. For each variable, the table reports the definition and the value range.

\begin{tabular}{|c|c|c|}
\hline Variable name & Definition & Range \\
\hline Age & Age of the individual in years & {$[0 ; \infty]$} \\
\hline Daily Wage & Earnings divided by Days Employed & {$[0 ; \infty]$} \\
\hline Days Employed & Sum of days in employment over all spells in one calender year & {$[0 ; 366]$} \\
\hline Earnings & Sum of income across all spells in one calendar year & {$[0 ; \infty]$} \\
\hline Employed & One unless unemployed or in vocational training & 0 or 1 \\
\hline Establishment Age & Years since first record of establishment in database & {$[0 ; \infty]$} \\
\hline Establishment Size (E) & Number of employees in establishment & {$[0 ; \infty]$} \\
\hline Establishment Wage & Average Daily Wage of employees in establishment & {$[0 ; \infty]$} \\
\hline Firm Tenure & Days in employment in current spell & {$[0 ; \infty]$} \\
\hline Fraction Employed & Days Employed divided by 366 & {$[0 ; 1]$} \\
\hline $\begin{array}{l}\text { Employment Growth } \\
\text { Rate (g) }\end{array}$ & $\begin{array}{l}\text { Employment growth rate of establishment } j \text { from time } t \text { to } \\
\text { time } t+k \text {, see Appendix Section A.3 for a precise definition }\end{array}$ & {$[-2 ; 2]$} \\
\hline Hiring Rate ( $h$ ) & $\begin{array}{l}\text { Flow of newly hired employees of establishment } j \text { from time } t \\
\text { to time } t+k \text {, see Appendix A.3 for a precise definition }\end{array}$ & {$[0 ; 2]$} \\
\hline IT-Integrated Job & $\begin{array}{l}\text { One if the job description includes the use of at least one Information } \\
\text { Technology (IT)-integrated tool as defined in Genz, Janser, and Lehmer (2019) }\end{array}$ & 0 or 1 \\
\hline IT-Related Job & $\begin{array}{l}\text { One if the job description is associated with an above median use } \\
\text { of IT related tools as defined in Genz, Janser, and Lehmer (2019) }\end{array}$ & 0 or 1 \\
\hline Manager & One if occupational group is equal to "Managers" (cf. Table 3) & 0 or 1 \\
\hline Offshorable Job & $\begin{array}{l}\text { One if high offshorability risk job as defined in Goos, Manning, and } \\
\text { Salomons (2014) }\end{array}$ & 0 or 1 \\
\hline Routine Job & $\begin{array}{l}\text { One if high routine intensity job as defined in Goos, Manning, and } \\
\text { Salomons (2014) }\end{array}$ & 0 or 1 \\
\hline Separation Rate (s) & $\begin{array}{l}\text { Flow of leaving employees of establishment } j \text { from time } t \text { to } \\
\text { time } t+k \text {, see Appendix A.3 for a precise definition }\end{array}$ & {$[0 ; 2]$} \\
\hline Target & One if employee is in target company & 0 or 1 \\
\hline Total Earnings & Sum of Earnings of all employees employed in an establishment & {$[0 ; \infty]$} \\
\hline Total Earnings Growth & Total Earnings growth rate, computed analogously to $g$ & {$[-2 ; 2]$} \\
\hline White Collar & $\begin{array}{l}\text { One if employee is associated with occupational groups (8), (9), or } \\
\text { (10) as defined in Table } 3\end{array}$ & 0 or 1 \\
\hline
\end{tabular}

\subsection{Constructing matched samples}

We perform a two-stage matching process in which we first match target establishments to control establishments and then draw control employees from a set of control establishments.

\subsubsection{Matching establishments}

For each target establishments, we identify 50 potential control establishments using the BHP and the following criteria. We remove all establishments from the BHP that have been targets themselves at any time during the sample period. ${ }^{8}$ We then build matching cells based on two-digit industry affiliation (60 categories), establishment size deciles, establishment age classes (ten classes: zero to two, three to five, six to ten, 11-15, 16-20, 21-25, and more than 25 years), and the buyout year (seven calendar years). This step is closely modeled on the process used by Davis et al. (2014) and results in 29,400 cells, of which 1,185 are filled after matching. Next, we pick the 50 nearest neighbors in terms of the Euclidean distance based on establishment size, establishment age, median establishment daily wage, the shares of medium-qualified, highly quali-

\footnotetext{
${ }^{8}$ We explored an alternative matching algorithm, in which we allow establishments to become controls as long as they have not been part of a buyout transaction in the five years before the matching year. The changes for the control sample would be negligible and affect at most $0.4 \%$ of the control establishments. We did not pursue this line of analysis further because the scope for look-ahead bias seems to be negligible.
}

fied, full-time, and female employees, and the average age of all employees.

For each target establishment, we identify the ten closest establishments out of the 50 potential control establishments based on the normalized Euclidean distance computed over establishment size, establishment age, mean establishment daily wage, the shares of mediumqualified, highly qualified, full-time employees, and female employees, and the average age of all employees. We match with replacement; i.e., a control establishment can be matched to more than one target establishment. Our final establishment data set contains 2,420 target establishments and 24,147 control establishments. We find at least six matches for each target establishment.

\subsubsection{Matching employees}

In the final step, we form a control group of matching employees. For each employee from the buyout group, we select a matching employee from one of the matched control establishments identified in the previous step. To base our matching on characteristics that have not been affected by the buyout, we match on characteristics recorded in the year before the buyout announcement. We match individuals exactly in terms of education, employment status, experience, gender, industry, nationality, occupation, qualification, and geographic location (region) (cf. Table OA2 in the Online Appendix for a detailed overview). We remove individuals for whom the absolute deviation from the target employee in terms of Earnings, Age, or Tenure is larger than 25\%, the absolute deviation in Establishment Size from 
the target employee is larger than $50 \%$, and the absolute deviation of Days Employed from the target employee is larger than 45 days. Finally, we pick the nearest neighbor based on the normalized Euclidean distance of the numerical variables.

We match with replacement; i.e., we allow for a control employee to be matched to more than one target employee. The final individual-level data set contains 152,057 target employees. We can match $74 \%$ of all target employees based on our criteria. The number of control employees is equal to 130,553 , which is smaller than the number of target employees because of matching with replacement.

\subsubsection{Matching success}

We match individuals exactly on the nine categorical variables listed in Section 2.2.2. For the five numerical variables, the relative differences between the target group and the control group are low or very low. (See Tables OA5 and OA6 in the Online Appendix for matching statistics.) We use the normalized differences proposed by Imbens and Wooldridge (2009) and used by Imbens and Rubin (2015) to examine significant differences between two groups of observations. Imbens and Wooldridge (2009) recommend that normalized differences be below 0.25 in absolute value. We record a test statistic of 0.13 for the fraction of full-time employees (Table OA6). For all other matching variables on both the establishment level and the individual level, the test statistic is never higher than 0.06, and we conclude that our control groups match target establishments and target employees very closely on all relevant criteria.

The differences between matched and unmatched buyout employees are substantial and largely the result of industry clustering of transactions. We have greater difficulty with matching part-time employees and those without vocational training. Hence, our analysis does not include these, arguably more vulnerable, groups of employees. Consequently, annual income and tenure are both substantially lower in the unmatched employee sample than in the matched employee sample.

\subsection{Descriptive statistics}

Table 2 presents descriptive statistics on the numerical variables. Our data set consists of 511 deals with 425 employees on average. Two-year pre-buyout employment growth is $13.36 \%$ on average, which shows that our sample is not dominated by restructuring buyouts. We observe each target establishment and each target individual over time from five years before the buyout to five years after the buyout. Our final data sets are panels of 185,969 establishment years and about 3.35 million individual years. The average employee is 42 years old and has held his or her current job for almost 9.5 years. A very small number of individuals enter our data set when they are still below working age because we track individuals starting five years before the buyout.

Table 3 describes the composition of the individuallevel sample with respect to qualification, gender, nationality, occupation, and education, separately for control employees and employees of PE buyout targets. The fourth column shows the composition of the whole labor force based on IAB data. The composition of the labor force is based on 2004 data, which is halfway between the first year (2001) and the last year (2007) of the sample we use for matching. PE buyouts target mostly manufacturing companies, which are overrepresented in the buyout sample (66.3\% of employees) relative to the economy in general (25.7\%). This bias reflects PE investors' tendency to acquire firms in manufacturing and the larger size of manufacturing targets (see Table OA3 in the Online Appendix on the industry composition of the deals in our sample). The higher weight of manufacturing in the sample characterizes all differences between the composition of the buyout sample and the German labor force. About a quarter of employees are grouped into the lowest occupational group of simple manual occupations, and only $17 \%$ of the general labor force belongs to this group. Managers constitute only $3.1 \%$ of the whole sample, in line with the general labor force. Women have a share of $24.4 \%$ in the sample, much less than the proportion of women in the labor force $(46.1 \%)$. The PE buyout sample is biased toward employees with an intermediate school leaving certificate and vocational training (69\%) compared with the German labor force (59\%), toward the south of Germany (49\% versus 38\%), and toward full-time workers (89\% versus 59\%), a consequence of comparatively poor matching of part-time employees.

\section{Employment and wages after private equity buyouts}

This section analyzes the development of employment and wages after PE buyouts at the establishment level (Section 3.1) and at the individual level (Section 3.2).

\subsection{Establishment-level analysis}

We build on Davis et al. (2014) and define the growth rate of employment from time $t$ to time $t+k$ as $g_{j, t, t+k}=$ $\frac{E_{j, t+k}-E_{j t}}{0.5\left(E_{j, t+k}+E_{j t}\right)}$, where $E_{j t}$ denotes the level of employment in establishment $j$ at time $t$. Subscript $t$ refers to points in time for stock measures (employment) and to periods for flow measures (e.g., separations). Precise definitions of all variables can be found in Table 1 . We regress one-year and multi-year growth rates of employment on a buyout-target indicator, the two-year pre-buyout growth rate, and a set of fixed effects:

$$
\begin{aligned}
g_{j, t-1+k, t+k}= & \alpha_{t}+\sum_{c} D_{c j} \delta_{c}+\lambda g_{j, t-3, t-1}+\theta_{k} \times \text { Target }_{j} \\
& +\varepsilon_{j, t+k}, k=0, \ldots, 5,
\end{aligned}
$$

where $D_{c j}$ is a set of dummy variables for cell $c$ for establishment $j$, in which cells are defined by the full cross product of buyout year, industry, firm size category, and firm age category (see Section 2). In Eq. (1), Target $_{j t}$ is a dummy variable equal to one for target establishments in all sample years. We follow Davis et al. (2014) and control for past employment growth using $g_{j, t-3, t-1}$, even in regressions in which the dependent variable is not employment growth. 


\section{Table 2}

Descriptive statistics.

This table provides descriptive statistics for all numerical variables. The establishment-level data set consists of 2,420 target establishments, 24,147 control establishments, and seven years of observations: $(2,420+24,147) \times 7=$ 185,969 establishment-year observations. The individual-level data set consists of 152,057 target employees, the same number of control employees, and 11 years of observations: $152,057 \times 2 \times 11=3,345,254$ individual-year observations. "Pre-buyout growth rate" denotes the growth of deal-level employment from the end of $t-3$ to the end of $t-1$. All other variables are defined in Table 1.

\begin{tabular}{lcccccc}
\hline Variable name & $N$ & Mean & Median & Minimum & Maximum & $\begin{array}{c}\text { Standard } \\
\text { deviation }\end{array}$ \\
\hline Panel A: Deal statistics & & & & & & \\
Employees & 511 & 425 & 182 & 10 & 8,902 & 825 \\
Pre-buyout growth rate & 511 & $13.36 \%$ & $4.14 \%$ & $-178.64 \%$ & $200.00 \%$ & $49.34 \%$ \\
Panel B: Establishment-level data set & & & & & & \\
Establishment Size (E) & 185,969 & 77 & 19 & 0 & 8,257 & 205 \\
Growth Rate (g) & 185,969 & $-3.62 \%$ & $0.00 \%$ & $-200.00 \%$ & $200.00 \%$ & $54.83 \%$ \\
Hiring Rate (h) & 185,969 & $25.62 \%$ & $15.38 \%$ & $0.00 \%$ & $200.00 \%$ & $34.13 \%$ \\
Separation Rate (s) & 185,969 & $29.23 \%$ & $16.00 \%$ & $0.00 \%$ & $200.00 \%$ & $41.26 \%$ \\
Panel C: Individual-level data set & & & & & & \\
Age & $3,345,254$ & 42 & 42 & 10 & 81 & 11 \\
Daily Wage & $3,071,118$ & 102 & 99 & 0 & 1,663 & 42 \\
Days Employed & $3,345,254$ & 329 & 365 & 0 & 366 & 98 \\
Earnings & $3,345,254$ & 34,251 & 34,474 & 0 & 207,583 & 17,505 \\
Firm Tenure & $3,345,254$ & 3291 & 2374 & 0 & 14,245 & 3069 \\
Fraction Employed & $3,345,254$ & 1 & 1 & 0 & 1 & 0 \\
IT-Integrated Job & $3,345,254$ & $26 \%$ & $0 \%$ & $0 \%$ & $100 \%$ & $44 \%$ \\
IT-Related Job & $3,345,254$ & $46 \%$ & $0 \%$ & $0 \%$ & $100 \%$ & $50 \%$ \\
Offshorable Job & $3,210,327$ & $62 \%$ & $100 \%$ & $0 \%$ & $100 \%$ & $49 \%$ \\
Routine Job & $3,287,989$ & $48 \%$ & $0 \%$ & $0 \%$ & $100 \%$ & $50 \%$ \\
\hline
\end{tabular}

All establishment-level regressions are weighted, with weights proportional to employment to give larger establishments a higher weight. ${ }^{9}$ Throughout the paper, we report $t$-statistics and significance levels based on standard errors clustered at the firm level (see Petersen, 2009; Abadie et al., 2017). We discuss some of the issues related to firm-level clustering and deal-level clustering in Appendix Section A.1, where we also discuss further robustness checks.

We are interested in decomposing establishment-level employment growth after PE buyouts into separations and new hires. Let $H_{j t}\left(S_{j t}\right)$ be the number of employees who enter (leave) establishment $j$ in period $t$, and denote the normalized flow of newly hired employees by $h_{j t}=\frac{H_{j t}}{0.5\left(E_{j t}+E_{j, t-1}\right)}$, analogously for the separation rate $s_{j t}$. With these definitions, $g_{j, t-1, t}=h_{j t}-s_{j t}$. (See Appendix Section A.3 for further details.) We estimate Eq. (1) with $g_{j, t-1, t}, h_{j t}$, and $s_{j t}$ as dependent variables, but with the same set of controls and independent variables as in Eq. (1). The coefficients of interest are the difference-indifferences estimates of $\theta_{k}(g)\left[\theta_{k}(h), \theta_{k}(s)\right]$, which measure by how much the employment growth rate (hiring rate, separation rate) for buyout establishments exceeds that of matching control establishments. The coefficients have to add up such that $\theta_{k}(g)=\theta_{k}(h)-\theta_{k}(s)$, i.e., the establishment growth rate equals the difference between hiring rate and separation rate.

\footnotetext{
${ }^{9}$ We divide our sample into three subsamples based on deal size and repeat the analysis in Table OA4 in the Online Appendix, which shows that our results are not driven by a small number of deals with very large establishments.
}

We caution the reader to be careful with causal interpretations of these coefficients. While we take great care with our matching algorithm (see Section 2.2.3), matching relies on observables. We cannot measure output, labor productivity, the quality of management, or other characteristics of the workforce that could be relevant for buyers in private equity buyouts and could give rise to selection effects.

The results of this analysis are in Table 4. Panel A shows the results for regressions with one-year employment growth rates, annual separation rates, and annual hiring rates for the event year $t$ and each of the subsequent five years after the buyout. We observe a longterm, cumulative establishment-level employment decline between periods $t$ and $t+5$ of 8.96\%. ${ }^{10}$ Kaplan (1989) finds industry-adjusted employment losses at buyout targets of $6.2 \%$ to $12.0 \%$ for an earlier sample. For the UK, Wright et al. (1992) report employment losses for buyouts of 6.3\% with a subsequent recovery. Lichtenberg and Siegel (1990) find an $8.5 \%$ decline over three years, and Davis et al. (2014) find only $2.6 \%$ for a comparable period. Overall, the large literature on this topic (Wright et al. (2009) review 17 papers on employment effects) tends to find comparable long-term effects of leveraged buyouts (LBOs), albeit with significant variation across studies.

From Table 4, the net cumulative employment decline of $8.96 \%$ can be decomposed into an increase in

\footnotetext{
10 Our results correspond to what Davis et al. (2014) describe as a semiparametric regression with homogeneous treatment effects across the cells defined in the matching process (see Section 2.2.1). In unreported results, we reproduce their nonparametric specification. The results are not much different from the semiparametric results, neither in their case nor in ours, and are, therefore, not reported.
} 
Table 3

Sample description.

This table provides an overview of our sample with respect to our categorical variables. Occupational groups are based on the job classification scheme provided in Blossfeld (1987, p. 99). "Semi-professions" are service-oriented jobs with a high degree of scientific education, such as nurses, social workers, and secondary school teachers. "Professions" covers service-oriented jobs with a very high degree of scientific education, e.g., physicians, judges, and pharmacists. "Managers" contains both executives and mid-level managers. Each occupational group is assigned a level of qualification (low, medium, high). "Intermediate secondary school degree" indicates that the person graduated from a secondary school after nine or ten years of schooling. "High school degree" indicates that the person graduated after 12 or 13 years of schooling with a German "Abitur." The exact number of years depends on school type and state. "Immigrant population" covers employees who are citizens of Italy or Turkey or who are from a former Yugoslavian country. Our sample contains 152,057 private equity (PE) buyout employees, the same number of control employees, and 56,392 unmatched PE buyout employees. The statistics are based on the year prior to the transaction.

\begin{tabular}{|c|c|c|c|c|}
\hline Category & $\begin{array}{c}\text { Target } \\
\text { employees (\%) }\end{array}$ & $\begin{array}{l}\text { Control } \\
\text { employees }(\%)\end{array}$ & $\begin{array}{l}\text { Unmatched } \\
\text { employees (\%) }\end{array}$ & $\begin{array}{l}\text { Total } \\
\text { labor force }(\%)\end{array}$ \\
\hline \multicolumn{5}{|l|}{ Occupational group (qualification) } \\
\hline (1) Simple manual occupations (low) & 24.8 & 24.8 & 20.8 & 17.1 \\
\hline (2) Skilled manual occupations (medium) & 20.0 & 20.0 & 15.5 & 14.3 \\
\hline (3) Technicians and engineers (high) & 16.7 & 16.7 & 7.6 & 6.3 \\
\hline (4) Simple service (low) & 8.3 & 8.3 & 14.1 & 19.7 \\
\hline (5) Qualified service (medium) & 0.7 & 0.7 & 2.2 & 3.3 \\
\hline (6) Semi-professions (medium) & 0.5 & 0.5 & 1.8 & 4.6 \\
\hline (7) Professions (high) & 0.6 & 0.6 & 2.1 & 1.9 \\
\hline (8) Simple commercial and administrative occupations (low) & 6.4 & 6.4 & 12.3 & 11.4 \\
\hline (9) Qualified commercial and administrative occupations (medium) & 19.0 & 19.0 & 20.8 & 19.0 \\
\hline (10) Managers (high) & 3.1 & 3.1 & 2.6 & 2.3 \\
\hline Females & 24.4 & 24.4 & 42.0 & 46.1 \\
\hline \multicolumn{5}{|l|}{ Nationality } \\
\hline German & 93.6 & 93.6 & 86.5 & 89.8 \\
\hline Immigrant population & 4.3 & 4.3 & 6.1 & 5.1 \\
\hline Rest of the world & 2.1 & 2.1 & 7.4 & 5.1 \\
\hline \multicolumn{5}{|l|}{ Occupational status } \\
\hline Vocational training & 1.5 & 1.5 & 19.8 & 7.8 \\
\hline Full-time employees & 88.7 & 88.7 & 51.4 & 58.7 \\
\hline Home worker & 0.1 & 0.1 & 0.2 & 0.1 \\
\hline Part-time employees & 9.7 & 9.7 & 28.5 & 33.8 \\
\hline \multicolumn{5}{|l|}{ Education } \\
\hline \multicolumn{5}{|l|}{ Intermediate secondary school degree } \\
\hline Without vocational training (low) & 10.9 & 10.8 & 32.5 & 23.3 \\
\hline With vocational training (medium) & 69.2 & 69.2 & 47.5 & 58.7 \\
\hline \multicolumn{5}{|l|}{ High school degree } \\
\hline Without vocational training (medium) & 0.9 & 1.0 & 3,0 & 3.4 \\
\hline With vocational training (high) & 5.5 & 5.5 & 6.5 & 5.8 \\
\hline College or university degree (high) & 13.5 & 13.6 & 10.5 & 8.9 \\
\hline \multicolumn{5}{|l|}{ Industries } \\
\hline Manufacturing & 66.3 & 66.3 & 27.4 & 25.7 \\
\hline Retail, maintenance and repair services & 13.2 & 13.2 & 14.6 & 17.3 \\
\hline Real estate & 13.6 & 13.6 & 20.4 & 15.1 \\
\hline Telecommunications & 3.9 & 3.9 & 5.6 & 5.5 \\
\hline Construction & 1.4 & 1.4 & 3.1 & 6.3 \\
\hline All other & 1.6 & 1.6 & 28.9 & 30.1 \\
\hline \multicolumn{5}{|l|}{ Region } \\
\hline North (Schleswig-Holstein, Hamburg, Lower Saxony, Bremen) & 14.0 & 14.0 & 17.6 & 15.6 \\
\hline $\begin{array}{l}\text { East (Berlin, Brandenburg, Mecklenburg-Vorpommern, } \\
\text { Saxony, Saxony-Anhalt, Thuringia) }\end{array}$ & 11.4 & 11.4 & 15.6 & 18.2 \\
\hline South (Hessen, Baden-Wuerttemberg, Bavaria) & 49.2 & 49.2 & 43.4 & 38.4 \\
\hline West (North Rhine-Westphalia, Rhineland-Palatinate, Saarland) & 25.5 & 25.5 & 23.4 & 27.7 \\
\hline
\end{tabular}

separations associated with PE buyouts of $18.75 \%$ and a $9.79 \%$ increase in the hiring rate. Similar to Davis et al. (2014), we observe that PE buyouts are associated with a simultaneous increase in the layoff rate and the hiring rate, a process they describe as creative destruction. Table 4 shows the ratio of the coefficients $\theta(h) / \theta(s)$. Over the five-year period after the buyout, about half of the buyout-related separations are replaced by new hires, and the other half of the jobs are lost permanently.

To further explore the pattern of separations and hiring we rerun Eq. (1) for rates from the event year to year $t+5$ separately for each deal in our sample and obtain 511 estimates of $\theta_{f}(h)$ and $\theta_{f}(s)$. We plot $\theta_{f}(s)$ against $\theta_{f}(h)$ in Fig. 1. The cross-sectional correlation between $\theta_{f}(h)$ and $\theta_{f}(s)$ is $48.7 \%$. Post-buyout separation rates and hiring rates, each calculated relative to a control group, tend to be strongly positively correlated, and about half of the deals are followed by increased separation and hiring rates.

The time-series patterns of hiring, job losses, and employment decline reveal a phase-shift in this development. In the event year and the subsequent two years, the buyout-related cumulative separation rate is low at 
Table 4

Establishment-level aggregate employee flows.

The table reports estimated employment growth rates and coefficients $\theta$ between targets and controls in the buyout year $(t=0)$ and subsequent years from Eq. (1). In every regression, we control for each of our matching cells based on two-digit industry, buyout year, Establishment Age, and Establishment Size. See Section 2.2 for further details. In addition, we control for prebuyout growth $g_{j, t-3, t-1}$. The coefficient $\theta$ denotes the coefficient $\theta(g)$ if the dependent variable in Eq. (1) is employment growth, $\theta(s)$ if the dependent variable is the separation rate, and $\theta(h)$ when the dependent variable is the hiring rate (see Appendix Section A.3 for definitions of growth rates, separation rates, and hiring rates). The variables are defined in Table 1. Each reported coefficient is for a different semiparametric, employment-weighted regression. For example, in " $t+2$," we report $\theta(g)$, which is calculated for the one-year growth rate $g_{j, t+1, t+2}$ from $t+1$ to $t+2$ following the buyout. In " $t$ to $t+2$," we report the estimated differences from the beginning of the event-year until the end of the second year after the event-year. The number of observations is 26,567 (2,420 target establishments and 24,147 control establishments). $\theta(h) / \theta(s)$ denotes the ratio of the coefficients. In Panel B, we perform a sample split into public targets and private targets. Standard errors are clustered at the firm level and we present the corresponding $t$-statistics below the coefficient estimates. ${ }^{*},{ }^{* *}$, and ${ }^{* * *}$ indicate significance at the $10 \%, 5 \%$, and $1 \%$ level, respectively.

\begin{tabular}{|c|c|c|c|c|c|}
\hline \multirow[b]{2}{*}{ Period } & \multicolumn{5}{|c|}{ Dependent variable } \\
\hline & $\begin{array}{c}\text { Employment growth } \\
\text { Rate }[\theta(g)] \\
\text { (1) }\end{array}$ & $\begin{array}{l}\text { Separation } \\
\text { Rate }[\theta(s)] \\
\quad(2)\end{array}$ & $\begin{array}{c}\text { Hiring } \\
\text { Rate }[\theta(h)] \\
\quad(3)\end{array}$ & $\begin{array}{c}\theta(h) / \theta(s) \\
(4)\end{array}$ & $\begin{array}{l}\text { Total earnings } \\
\text { Growth } \\
\text { (5) }\end{array}$ \\
\hline \multicolumn{6}{|c|}{ Panel A: Growth rates and worker flows } \\
\hline$t$ & $\begin{array}{c}-0.0092 \\
-0.65\end{array}$ & $\begin{array}{l}0.0229^{* *} \\
2.25\end{array}$ & $\begin{array}{c}0.0137 \\
1.48\end{array}$ & $60 \%$ & $\begin{array}{c}0.0018 \\
0.12\end{array}$ \\
\hline$t+1$ & $\begin{array}{c}-0.0053 \\
-0.39\end{array}$ & $\begin{array}{c}0.0230^{* *} \\
2.21\end{array}$ & $\begin{array}{c}0.0177^{* *} \\
1.98\end{array}$ & $77 \%$ & $\begin{array}{c}-0.0027 \\
-0.21\end{array}$ \\
\hline$t+2$ & $\begin{array}{c}-0.0050 \\
-0.55\end{array}$ & $\begin{array}{l}0.0189^{* * *} \\
2.59\end{array}$ & $\begin{array}{l}0.0138^{* *} \\
2.23\end{array}$ & $73 \%$ & $\begin{array}{c}-0.0019 \\
-0.21\end{array}$ \\
\hline$t+3$ & $\begin{array}{c}-0.0353^{* * *} \\
-3.02\end{array}$ & $\begin{array}{l}0.0422^{* * *} \\
3.83\end{array}$ & $\begin{array}{c}0.0069 \\
1.23\end{array}$ & $16 \%$ & $\begin{array}{c}-0.0295^{* *} \\
-2.46\end{array}$ \\
\hline$t+4$ & $\begin{array}{c}-0.0187 \\
-0.94\end{array}$ & $\begin{array}{c}0.0341^{*} \\
1.85\end{array}$ & $\begin{array}{c}0.0154^{* *} \\
2.17\end{array}$ & $45 \%$ & $\begin{array}{c}-0.0237 \\
-1.24\end{array}$ \\
\hline$t+5$ & $\begin{array}{c}-0.0186 \\
-1.21\end{array}$ & $\begin{array}{c}0.0298^{* *} \\
2.31\end{array}$ & $\begin{array}{c}0.0112 \\
1.34\end{array}$ & $38 \%$ & $\begin{array}{c}-0.0176 \\
-1.17\end{array}$ \\
\hline$t$ to $t+2$ & $\begin{array}{c}-0.0186 \\
-0.89\end{array}$ & $\begin{array}{l}0.0594^{* * *} \\
3.11\end{array}$ & $\begin{array}{l}0.0407^{* *} \\
2.47\end{array}$ & $68 \%$ & $\begin{array}{c}-0.0088 \\
-0.41\end{array}$ \\
\hline$t$ to $t+5$ & $\begin{array}{l}-0.0896^{* * *} \\
-2.61\end{array}$ & $\begin{array}{l}0.1875^{* * * *} \\
\quad 4.45\end{array}$ & $\begin{array}{l}0.0979 * * * \\
2.83\end{array}$ & $52 \%$ & $\begin{array}{l}-0.0787^{* *} \\
-2.14\end{array}$ \\
\hline \multicolumn{6}{|c|}{ Panel B: Sample split into public targets and private targets } \\
\hline \multicolumn{6}{|c|}{ Public targets $(N=87)$} \\
\hline$t$ to $t+2$ & $\begin{array}{c}-0.0282 \\
-0.67\end{array}$ & $\begin{array}{c}0.0581^{*} \\
1.74\end{array}$ & $\begin{array}{c}0.0299 \\
0.71\end{array}$ & $52 \%$ & $\begin{array}{c}-0.0154 \\
-0.37\end{array}$ \\
\hline$t$ to $t+5$ & $\begin{array}{l}-0.1376^{* *} \\
-2.26\end{array}$ & $\begin{array}{l}0.1605^{* * *} \\
2.98\end{array}$ & $\begin{array}{c}0.0229 \\
0.34\end{array}$ & $14 \%$ & $\begin{array}{l}-0.1322^{* *} \\
-2.02\end{array}$ \\
\hline \multicolumn{6}{|c|}{ Private targets $(N=424)$} \\
\hline$t$ to $t+2$ & $\begin{array}{c}-0.0173 \\
-0.73\end{array}$ & $\begin{array}{l}0.0599^{* * *} \\
2.69\end{array}$ & $\begin{array}{l}0.0426^{* * *} \\
2.61\end{array}$ & $71 \%$ & $\begin{array}{c}-0.0081 \\
-0.34\end{array}$ \\
\hline$t$ to $t+5$ & $\begin{array}{c}-0.0773^{*} \\
-1.93\end{array}$ & $\begin{array}{l}0.1921^{* * * *} \\
3.74\end{array}$ & $\begin{array}{l}0.1148^{* * *} \\
3.02\end{array}$ & $60 \%$ & $\begin{array}{c}-0.0648 \\
-1.52\end{array}$ \\
\hline
\end{tabular}

$5.94 \%$, so $68 \%$ of buyout-related separations are replaced, as measured by the ratio $\theta(h) / \theta(s)$, resulting in a small cumulative employment decline of $1.86 \%$. If we cumulate the rates for three to five years after the transaction, we can observe how this pattern changes. The buyoutrelated cumulative separation rate increases to $10.61 \%$ $(=4.22 \%+3.41 \%+2.98 \%)$ and the cumulative hiring rate decreases to $3.35 \%(=0.69 \%+1.54 \%+1.12 \%)$. The replacement ratio $\theta(h) / \theta(s)$ drops to about $0.3(=3.35 \% / 10.61 \%)$, resulting in a more pronounced employment decline of about $1.81 \%$. The years in the immediate aftermath of the transaction could be characterized as years of creative destruction, with comparable increases in the separation rate and the hiring rate, and later years seem to be characterized more by streamlining, associated with more job losses and less replacement. We conjecture that PE investors emphasize streamlining and cost-cutting in later years because their investments have a finite time horizon. As they approach the time when they want to resell target companies or take them public, cost-cutting could become more important. Alternatively, PE investors could take time to evaluate operations in a newly acquired firm and to implement reorganization measures, which could also explain why separations do not happen immediately after buyouts.

Finally, Column 5 of Table 4 reports the same regression results with the growth of total earnings as the dependent variable. Total earnings of an establishment are defined as the sum of income earned in this establishment for all employees who have been employed at that establishment at the end of the calendar year. The post-buyout development 


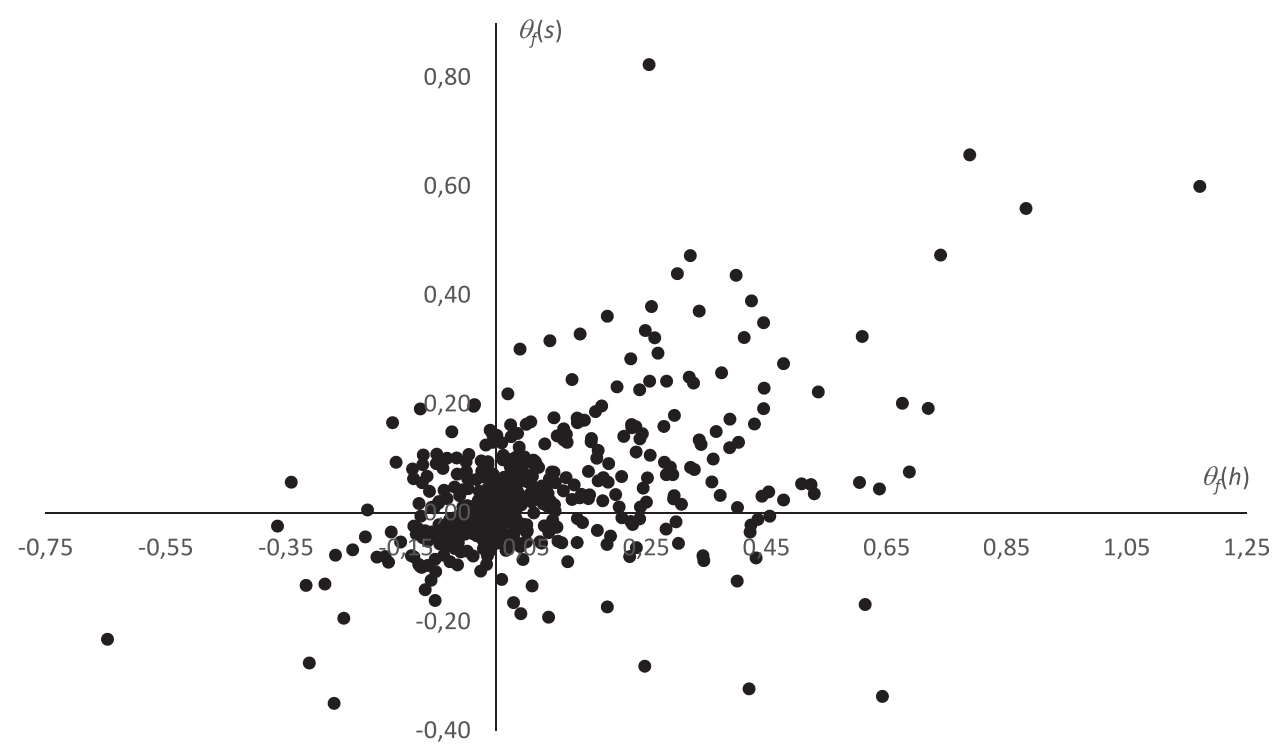

Fig. 1. Deal-level hiring and separation rates. The figure plots the coefficients $\theta_{f}(s)$ against $\theta_{f}(h)$ from estimating Eq. (1) for rates from the event year to year $t+5$ separately for each deal in the sample. The cross-sectional correlation between $\theta_{f}(h)$ and $\theta_{f}(s)$ is $48.7 \%$. Of the 511 deals, $234(46 \%)$ have positive estimates for both $\theta_{f}(h)$ and $\theta_{f}(s)$, and $122(24 \%)$ have negative values for both; 74 deals $(14.5 \%)$ have $\theta_{f}(h)<0$ and $\theta_{f}(s)>0$; and 81 deals $(15.9 \%)$ have $\theta_{f}(h)>0$ and $\theta_{f}(s)<0$.

for earnings growth and employment growth would differ between target and control establishments if PE firms would systematically replace high-earning employees with employees who earn less to cut costs, or if they would do the opposite, e.g., to attract more qualified employees. The development of establishment-level earnings growth mirrors that of employment growth, suggesting no systematic bias toward hiring or laying off better-paid employees.

Panel B of Table 4 reports a sample split of the establishments into public versus private targets. The split according to public status shows that the coefficients $\theta(s)$ on separation rates in the two subsamples are virtually identical, but those on hiring rates, $\theta(h)$, are much higher for private targets than for public targets. Consequently, employment growth is lower for public targets than for private targets. On average, it is negative for both groups, and the difference is statistically not significant. ${ }^{11}$ These results stand in contrast to Davis et al. (2014), who observe positive growth for private targets. Their results are at the firm level and include the employment effects of starting new establishments. In Table OA7 in the Online Appendix, we perform an individual-level analysis to investigate if employees of public targets fare differently after buyouts. We cannot find any significant differences.

\subsection{Individual-level analyses}

Our approach for the individual-level analysis builds on Jacobson et al. (1993) and Couch and Placzek (2010), who use panel regressions with fixed effects and matching estimators in a program evaluation context. We define three main outcome variables $Y_{i t}$.

\footnotetext{
11 The aggregate effect is now positive, and these data are available for
} only about $40 \%$ of the sample.
(1) Earnings-The employee's earnings summed up over all employment spells in a given year.

(2) Daily Wage-Earnings of employee $i$ in year $t$, divided by the number of days employed during that year. Daily Wage is set to missing if the employee or the employee's match was unemployed during the whole year t. ${ }^{12}$

(3) Days Employed-The number of days in year $t$ during which employee $i$ was employed.

Our analysis relies on matched-sample difference-indifferences regressions:

$Y_{i t}=\alpha_{i}+\gamma_{t}+\sum_{k=-5}^{k=+5} \delta_{k} D_{i k}+$ Target $_{i} \times \sum_{k=-5}^{k=+5} \theta_{k} D_{i k}+\varepsilon_{i k}$.

In Eq. (2), $Y_{i t}$ denotes the outcome variable in levels (Earnings, Daily Wage, Days Employed, or their logarithms), $\alpha_{i}$ and $\gamma_{t}$ are, respectively, individual and calendar-year fixed effects, $i$ indexes individuals, $t$ indexes calendar time, and $k$ indexes event time. In all cases, when we refer to the logarithm of a variable $Y$, we use the transformation $\ln (1+Y) .{ }^{13}$ The event time dummy variables $D_{i k}$ begin five years before the buyout $(k=-5)$ and end five years after the buyout $(k=+5)$. Our data cover all individuals from five years before to five years after the event, and the dummies for the year before the event $(k=-1)$ are omitted.

\footnotetext{
12 We cannot calculate hourly wages, because our data do not report the number of hours worked per day or per week. According to Table 3, 6\% of our sample are part-time employees for whom Daily Wage will be lower than a full-time equivalent daily wage.

13 This transformation is commonly applied but not necessarily without problems if $Y$ is small relative to one. See Burbidge et al. (1988) and Pence (2006) for further discussion. Because the values of all our variables $Y$ are orders of magnitude larger than one, the resulting approximation error is very small.
} 


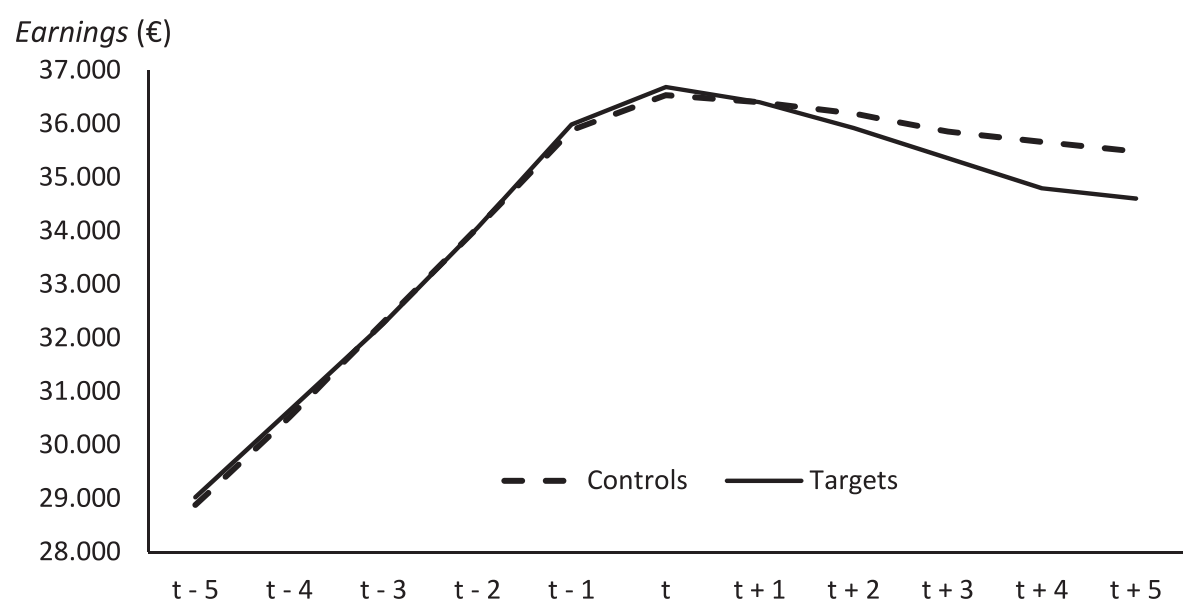

Fig. 2. Parallel trends analysis: Earnings. This figure presents the development of Earnings in event time. For every event-year, we compute the mean of Earnings for target employees and control employees separately. Earnings is defined in Table 1.

All event time effects thus are measured relative to the year before the buyout. The dummy variable Target $_{i}$ distinguishes employees of PE buyout targets from employees in the matched sample (controls) and equals one for target employees in all sample years. Clustering of standard errors is again at the firm level (see Appendix Section A.1 for further details).

The approach in Eq. (2) generalizes standard differencein-differences estimators by adding a temporal dimension to the standard dummy variable POST, which would assume a value of one in the post-buyout period. Eq. (2) differs from Jacobson et al. (1993) and Couch and Placzek (2010) by entering the event time dummies $D_{i k}$ in addition to the calendar time effects $\gamma_{t}$. PE buyouts happen at different dates in calendar time, so the event-year dummies are not collinear with calendar-year effects (see Boucly et al., 2011). The parameters of interest are the coefficients $\theta_{k}$ on the interactions $D_{i k} \times$ Target $_{i}$, which measure the average difference between target employees and control employees for the outcome variable $Y_{i t}$ in eventyear $k$. By contrast, the coefficients $\delta_{k}$ measure the average differences in event time, after controlling for calendar time effects. As in the case of the establishment-level analysis, we are careful with causal interpretations, because we cannot exclude selection effects; unobservable factors influence wages, employment, and buyout decisions.

We demonstrate that our data do not violate the parallel trends condition and show the trends before the event graphically for Earnings, Daily Wage, and Days Employed in Figs. 2 to 4 . The figures provide a first look at the individual-level data by showing the post-event trends as well. For all three variables, almost-perfect parallel developments are evident from $t-5$ to $t-1$. Daily Wage for both groups grows at a rate of about $2.4 \%$ per year. Days Employed trends upward for employees in the target and control groups from $t-5$ to $t-1$, peaking at 357 . The inverted- $\mathrm{V}$ pattern is a mechanical consequence of the requirement that employees in both groups have to be employed in the event year, but not necessarily before or after the event-year. (See Fig. 3A in Davis et al. (2014) for a similar effect.)
We begin with an analysis of the impact of PE buyouts on Earnings, defined as labor income summed across all employment spells of an employee in a given calendar year. Fig. 5 plots the coefficients $\theta_{k}$ on the interaction $D_{i k} \times$ Target $_{i}$ from Eq. (2) without controls except for person and calendar-year fixed effects. We tabulate the coefficients on $D_{k} \times$ Target in Table OA8 in the Online Appendix. Panel A of Fig. 5 reports results in euros and the number of days, and Panel B reports results in log points. Earnings decline steadily by $24 \mathrm{log}$ points over the six-year period from the beginning of the event year to the end of the fifth year after the event, to which we refer as the long term. The decline is $€ 979$ of annual income, which corresponds to $2.8 \%$ of the median wage for all target employees in the sample. The change in Earnings is very skewed, giving rise to more extreme estimates in terms of log points.

Lichtenberg and Siegel (1990) find that average annual compensation per production worker increases by $3.6 \%$ in the second year after the buyout and that non-production worker compensation falls by $5.2 \%$. Amess and Wright (2007) show that, in their sample of management buyouts and management buy-ins, buyouts have a $0.53 \%$ lower growth of income per worker compared with other firms. Davis et al. (2014) find reductions in annual earnings per worker. These studies look at the development of employees' total annual earnings for up to two years after the buyout.

We decompose the development of Earnings into a wage component and an employment component by studying the effects on Daily Wage (dashed line) and Days Employed (broken line). No measurable association exists of PE buyouts with Daily Wage, with a long-term decline of $€ 0.32$ per day ( $0.66 \log$ points) relative to a median of $€$ 99.29. Earlier studies on the employment effects of LBOs either do not analyze wages or look at annual earnings per worker, which corresponds to our definition of Earnings (see Wright et al. (2009) for a more extensive survey and the Introduction for a discussion of this literature). Employment of target employees declines by 8.83 days per year (13.6 log points) over the long term, which corresponds to $2.4 \%$ of the median of Days Employed. 
Daily Wage (€)

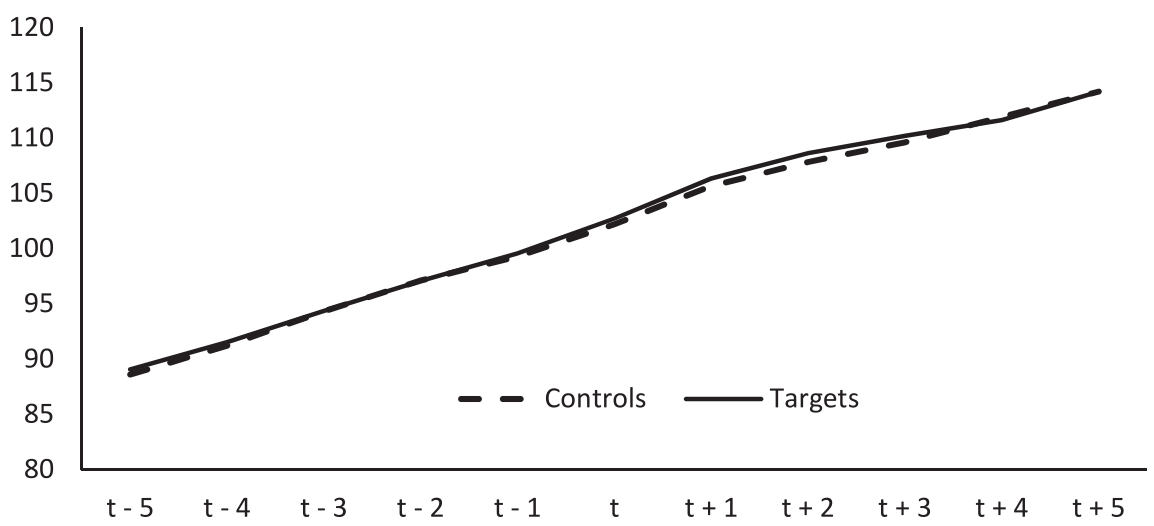

Fig. 3. Parallel trends analysis: Daily Wage. This figure presents the mean of Daily Wage for target employees and control employees separately. Daily Wage is defined in Table 1. Daily Wage is set to missing if Daily Wage of matched pair is missing in a given year.

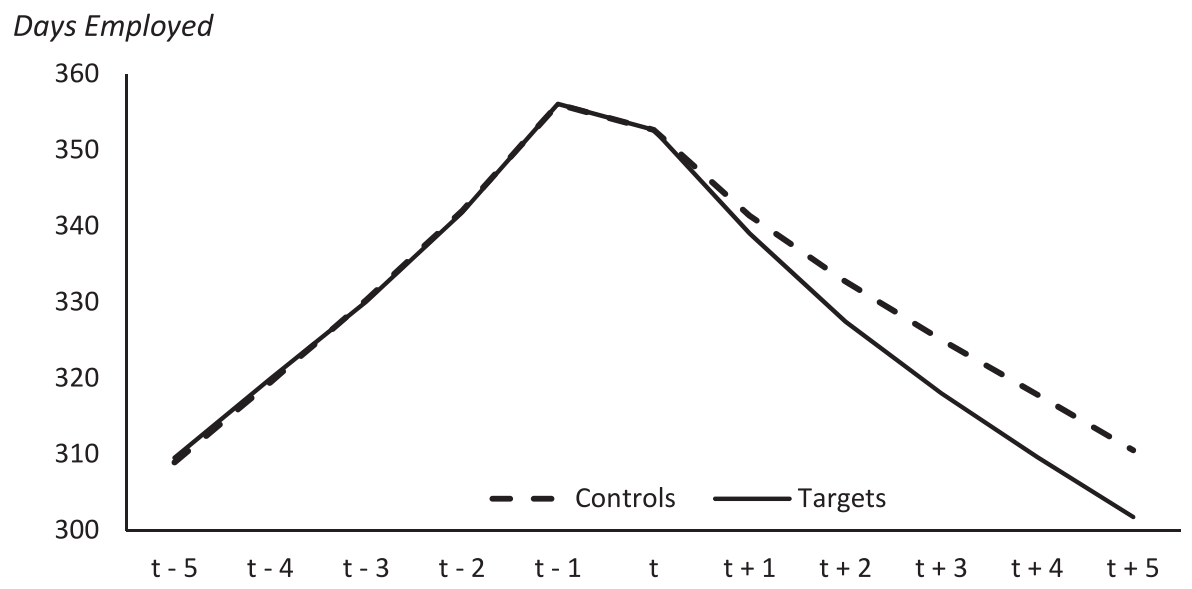

Fig. 4. Parallel trends analysis: Days Employed. This figure presents the mean of Days Employed for target employees and control employees separately. Days Employed is defined in Table 1. The inverted-V pattern is a mechanical consequence of the requirement that employees in both groups have to be employed in the event year, but not necessarily before or after the event-year.

\subsection{Job loss, unemployment, and career paths}

Comparing the results from establishment-level analyses and individual-level analyses allows us to make some tentative inferences about employees' post-buyout career paths. The long-term post-buyout separation rate of $18.75 \%$ reported in Table 4 translates into an employment decline of about $8.96 \%$. Note that the establishment sample covers more employees, as it includes unmatched employees, and the separations include employees who were hired after the buyout. Both groups do not appear in the individualemployee sample. If we assume that these two groups are not large or different enough to materially distort the picture, we can conclude that about half of the employees who are separated from buyout target firms find new employment.
To further analyze the importance of employees' postbuyout career paths, we repeat the analysis in Fig. 5, Panel A and Panel B, adding other control variables for career events. We add three dummy variables to Eq. (2): for switches to another establishment within the same three-digit industry, for switches to another establishment outside the employee's three-digit industry, and if the employee becomes unemployed. The variables always capture the status of the employee five years after the buyout. Panel $\mathrm{C}$ of Fig. 5 plots the estimates of $\theta_{k}$, which capture the interactions of the event time dummies with the target indicator, $D_{i k} \times$ Target $_{i}$. Panel $\mathrm{B}$ and Panel $\mathrm{C}$ are drawn to the same scale to make them comparable. After controlling for career-path events, the PE buyouts are not associated with individual-level declines of income, wages, and employment. Hence, career path events can 
Panel A: Earnings, wages, and employment

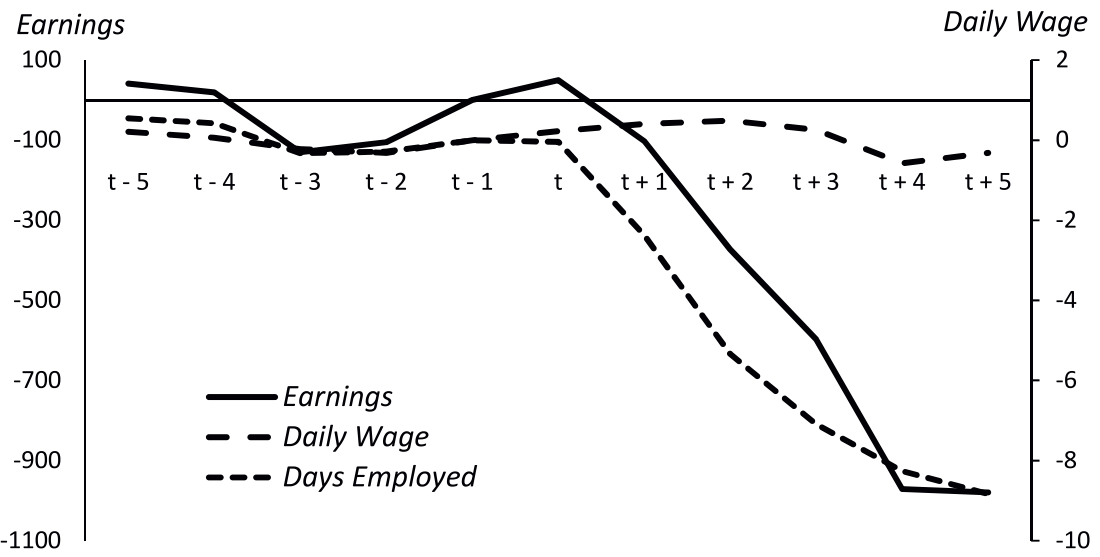

Panel B: Earnings (In), wages (In), and employment (In)

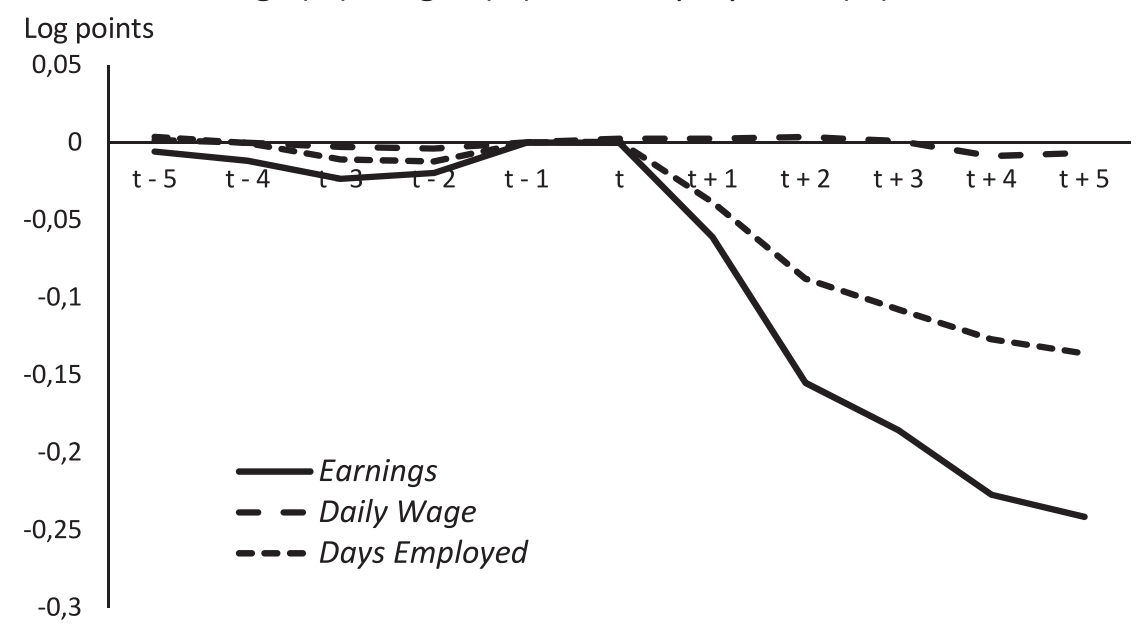

Panel C: Earnings (In), wages (In), and employment (In) with career path controls

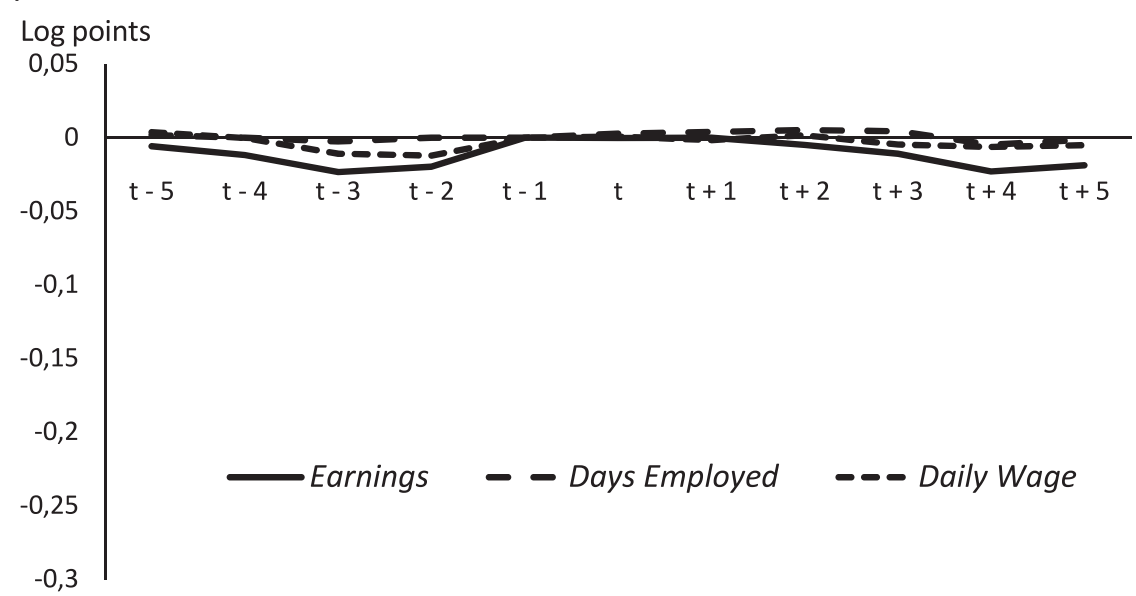

Fig. 5. The impact of private equity buyouts on wages and employment. The figure plots the coefficients $\theta_{k}$ on the interaction terms $D_{i k} \times$ Target $_{i}$ from ordinary least squares regressions of Earnings, Daily Wage, and Days Employed on a difference-in-differences setup and control variables as in Eq. (2). In Panel B, we use logarithmic transformations of the dependent variable. In Panel C, the regressions include dummy variables indicating switches to another establishment within the same three-digit industry, switches to another establishment outside the employee's three-digit industry, and unemployment. $D_{i k}$ is a dummy variable that is one for observations $k$ years after the event-year, where $k$ runs from five years before the buyout $(t-5)$ to five years after the buyout $(t+5)$. The dependent variables are in logs and defined in Table 1. Regressions control for person fixed effects and calendar-year fixed effects. 
account for the long-term post-buyout decline of income and employment.

\section{Who benefits and who loses after buyouts?}

In this section, we analyze how different groups of employees fare after buyouts. Our discussion is guided by three groups of theories that have been proposed in the literature on buyouts, each of which identifies employees with certain characteristics as likely losers or beneficiaries from buyouts. Section 4.2 analyzes organizational streamlining, and Section 4.3 investigates different variants of the technological-modernization argument. Finally, in Section 4.4, we address the question of whether private equity buyouts are primarily a mechanism to transfer wealth from employees to shareholders and to what extent they could breach implicit employment guarantees.

\subsection{Methodology}

All hypotheses we investigate in this section make contrasting predictions on the development of wages and employment for specific subgroups of employees relative to each other and identify several factors, such as workers' age, skill level, and the specificity of their human capital. We extend the methodologies of Sections 3.1 and 3.2 and incorporate employee characteristics into analyses at the establishment and the individual level. Each hypothesis identifies groups of employees who are more likely to suffer impairments of their human capital after buyouts. We refer to these characteristics as risk factors. For each group, we repeat the establishment-level analysis in Table 4 and test whether separation (hiring) rates after buyouts are particularly high (low) for groups of employees considered to be at risk in buyouts. All establishmentlevel analyses for groups of employees are presented in Table 5 for the period from the event-year to two years after the buyout. Table 6 provides the same analysis for rates calculated until five years after the buyout. Columns 1 to 3 report the $\theta$ coefficients from Eq. (1) for growth, separation, and hiring rates, respectively. Columns 4 to 6 of Panel A show tests for the differences between the group shown and all other employees, e.g., all managers and all non-managers. Columns 4 to 6 of Panel B show tests for the differences between the highest and lowest group. For example, the coefficient in Column 4 for Low Wage shows the difference between the estimates for High Wage - Low Wage and a $t$-test for whether this difference is significantly different from zero. For 12 of the 15 subgroups in Table 6, above-average (below-average) separation rates go along with above-average (below-average) hiring rates, i.e., departures by a certain category of employees is associated with increased hiring in the same category.

We perform individual-level triple-difference analyses, in which we interact the target indicator and event-time dummies with risk factors that identify the respective subgroups of employees. We build on Eq. (2) and estimate the triple-difference equation

$$
\begin{aligned}
Y_{i t}= & \alpha_{i}+\gamma_{t}+\sum_{k=-5}^{k=+5} \delta_{k} D_{i k}+\text { Target }_{i} \times \sum_{k=-5}^{k=+5} \theta_{k} D_{i k}+R F_{i}^{f} \\
& \times \sum_{k=-5}^{k=+5} \lambda_{k} D_{i k}+\text { Target }_{i} \times R F_{i}^{f} \times \sum_{k=-5}^{k=+5} \eta_{k} D_{i k}+\varepsilon_{i k} .
\end{aligned}
$$

The coefficients of interest in Eq. (3) are the $\eta_{k} \mathrm{~s}$ on the triple interaction of Target, the event dummies, and the risk factor, which measure by how much target employees characterized by risk factor $R F^{f}$ differ from control employees with the same risk factor and by how much target employees characterized by risk factor $R F^{f}$ differ from target employees not characterized by this risk factor. We run each regression for all three dependent variables, once in euros (Earnings, Daily Wage, Columns 1, 3) or days (Days Employed, Column 5) and once in logarithms (Columns 2, $4,6)$. All individual-level analyses based on Eq. (3) are presented in Table 7 . We report the estimates of only $\eta_{2}$ and $\eta_{5}$ to be consistent with the establishment analysis and to conserve space. In Table OA9 of the Online Appendix, we report all coefficient estimates for period $t$ to period $t+5$ for all risk factors yielding significant results. As before, we cluster standard errors at the firm level.

\subsection{Organizational streamlining}

One strand of the LBO literature sees PE buyouts as an organizational form that rivals the public corporation with dispersed shareholders (Jensen, 1989; Kaplan, 1989). This literature characterizes private equity firms as lean, decentralized organizations and argues that buyouts replace governance by direct monitoring with governance through high-powered incentives (Jensen, 1989; Lichtenberg and Siegel, 1990). For example, if top executives prefer a "quiet life" (Bertrand and Mullainathan, 2003), they can avoid confrontations with employees, pay higher wages, and favor middle management to keep conflicts from arising in their immediate work environment (Cronqvist et al., 2009). If buyout firms address these agency problems, buyout targets should reverse these trends. Based on these notions, we expect buyout targets to streamline their organizational structure by reducing the layers of management and creating a leaner organization. We hypothesize that these measures will fall disproportionately on white-collar workers and managers and expect a general decline in employment for these groups. Our data set includes two variables that allow us to analyze organizational restructuring. Manager is an indicator variable for those employees who have an executive or middle management position (occupational group 10 in Table 3). White Collar is an indicator variable for white-collar workers (occupational groups 8, 9, and 10), which form $28.5 \%$ of our sample (Table 3 ). Managers are a subset of white-collar employees and account for $3.1 \%$ of the sample and $11 \%$ of white-collar employees.

Table 5 shows that the short-term growth rate for white-collar workers is lower, reflecting a separation rate that is significantly higher (at the $10 \%$ level) than that for non-white-collar workers. The long-term effects in Table 6 point in the same direction but are not statistically significant. We observe economically and statistically significant increases in the long-term hiring and separation 
Table 5

Establishment-level and group-specific employee flows from $t$ to $t+2$.

This table replicates the analysis of Table 4 for specific groups. Rates are calculated over period $t$ to period $t+2$; i.e., growth rates are computed over a three-year period from the end of $t-1$ to the end of $t+2$. All variables are defined in Table 1. Wage terciles (low, medium, high) are based on Daily Wage. High and low splits are based on the median. Columns 1 to 3 report the coefficients $\theta$ from Regression 1 with growth rates (Column 1), separation rates (Column 2) and hiring rates (Column 3) as the dependent variable. Columns 4 to 6 provide tests for differences between groups of employees. In Panel A, the test is for whether these groups are different from their complement, e.g., White Collar minus all non-white-collar employees. In Panel B, the comparison is always for the difference between the highest and lowest quantile, e.g., High Wage minus Low Wage The number of observations varies per group because observations are missing when the establishment does not have at least one employee of the respective group and one point in time. The maximum number of observations is 24,700 (White Collar), and the minimum number is 11,364 (Manager). Standard errors are clustered at the firm level. $t$-statistics are provided below the coefficient estimates. ${ }^{*},{ }^{* *}$, and ${ }^{* * *}$ indicate significance at the $10 \%, 5 \%$, and $1 \%$ level, respectively.

\begin{tabular}{lcccccccc}
\hline Panel A: Occupational groups & & & & & \\
\hline & \multicolumn{3}{c}{ From $\boldsymbol{t}$ to $\boldsymbol{t}+\mathbf{2}$} & & \multicolumn{3}{c}{ Group - all other employees } \\
\cline { 2 - 4 } & Empl. Growth & Separation & Hiring & & Empl. Growth & Separation & Hiring \\
& Rate $[\theta(g)]$ & Rate $[\theta(s)]$ & Rate $[\theta(h)]$ & & Rate $[\theta(g)]$ & Rate $[\theta(s)]$ & Rate $[\theta(h)]$ \\
Group & $(1)$ & $(2)$ & $(3)$ & & $(4)$ & $(5)$ & $(6)$ \\
\hline White Collar & $-0.0468^{* *}$ & $0.0930^{* * *}$ & $0.0462^{* *}$ & & -0.0452 & $0.0534^{*}$ & 0.0078 \\
& -2.03 & & -1.29 & & 1.67 & 0.29 & \\
Manager & -0.0248 & $0.0725^{*}$ & $0.0477^{*}$ & & -0.0068 & 0.0137 & 0.0065 \\
& -0.65 & 1.95 & 1.77 & & -0.16 & 0.33 & 0.21 \\
IT-Related Job & -0.0313 & $0.0636^{* * *}$ & $0.0323^{* *}$ & & -0.0303 & 0.0100 & -0.0202 \\
& -1.52 & 3.03 & 2.12 & & -0.93 & 0.31 & -0.73 \\
IT-Integrated job & 0.0213 & 0.0453 & $0.0666^{* *}$ & & $0.0537^{*}$ & -0.0163 & 0.0374 \\
& 0.99 & 1.58 & 2.37 & & 1.72 & -0.47 & 1.14
\end{tabular}

Panel B: Group splits

\begin{tabular}{|c|c|c|c|c|c|c|}
\hline \multirow[b]{2}{*}{ Group } & \multicolumn{3}{|c|}{ From $t$ to $t+2$} & \multicolumn{3}{|c|}{ High - low } \\
\hline & $\begin{array}{c}\text { Empl. Growth } \\
\text { Rate }[\theta(g)] \\
\text { (1) }\end{array}$ & $\begin{array}{l}\text { Separation } \\
\text { Rate }[\theta(s)] \\
\text { (2) }\end{array}$ & $\begin{array}{c}\text { Hiring } \\
\text { Rate }[\theta(h)] \\
\text { (3) }\end{array}$ & $\begin{array}{c}\text { Empl. Growth } \\
\text { Rate }[\theta(g)] \\
(4)\end{array}$ & $\begin{array}{c}\text { Separation } \\
\text { Rate }[\theta(s)] \\
\text { (5) }\end{array}$ & $\begin{array}{c}\text { Hiring } \\
\text { Rate }[\theta(h)] \\
\quad(6)\end{array}$ \\
\hline Low Wage & $\begin{array}{c}-0.0440 \\
-1.15\end{array}$ & $\begin{array}{c}0.1160^{* * *} \\
3.06\end{array}$ & $\begin{array}{c}0.0720^{* *} \\
2.51\end{array}$ & $\begin{array}{c}0.0424 \\
0.88\end{array}$ & $\begin{array}{c}-0.0800^{*} \\
-1.74\end{array}$ & $\begin{array}{c}-0.0376 \\
-1.06\end{array}$ \\
\hline Medium Wage & $\begin{array}{c}-0.0146 \\
-0.40\end{array}$ & $\begin{array}{c}0.0604^{*} \\
1.91\end{array}$ & $\begin{array}{c}0.0458^{* * *} \\
2.70\end{array}$ & & & \\
\hline High Wage & $\begin{array}{c}-0.0016 \\
-0.06\end{array}$ & $\begin{array}{c}0.0360 \\
1.38\end{array}$ & $\begin{array}{c}0.0344 \\
1.63\end{array}$ & & & \\
\hline Low Routine Job & $\begin{array}{c}-0.0295 \\
-1.39\end{array}$ & $\begin{array}{c}0.0768^{* * *} \\
3.57\end{array}$ & $\begin{array}{c}0.0473^{* *} \\
2.43\end{array}$ & $\begin{array}{c}0.0152 \\
0.48\end{array}$ & $\begin{array}{c}-0.0310 \\
-1.02\end{array}$ & $\begin{array}{c}-0.0157 \\
-0.62\end{array}$ \\
\hline High Routine Job & $\begin{array}{c}-0.0143 \\
-0.61\end{array}$ & $\begin{array}{c}0.0458^{* *} \\
2.15\end{array}$ & $\begin{array}{c}0.0316^{*} \\
1.92\end{array}$ & & & \\
\hline Low Offshorable Job & $\begin{array}{c}-0.0111 \\
-0.54\end{array}$ & $\begin{array}{c}0.0576^{* * *} \\
2.62\end{array}$ & $\begin{array}{c}0.0465^{* *} \\
2.42\end{array}$ & $\begin{array}{c}-0.0204 \\
-0.59\end{array}$ & $\begin{array}{c}0.0119 \\
0.39\end{array}$ & $\begin{array}{c}-0.0084 \\
-0.30\end{array}$ \\
\hline High Offshorable Job & $\begin{array}{c}-0.0315 \\
-1.14\end{array}$ & $\begin{array}{c}0.0695^{* * *} \\
3.25\end{array}$ & $\begin{array}{c}0.0381^{*} \\
1.92\end{array}$ & & & \\
\hline Young & $\begin{array}{c}-0.0090 \\
-0.41\end{array}$ & $\begin{array}{c}0.0466^{* *} \\
2.35\end{array}$ & $\begin{array}{c}0.0376^{* *} \\
2.09\end{array}$ & $\begin{array}{c}-0.0147 \\
-0.46\end{array}$ & $\begin{array}{c}0.0106 \\
0.37\end{array}$ & $\begin{array}{c}-0.0041 \\
-0.18\end{array}$ \\
\hline Old & $\begin{array}{c}-0.0237 \\
-1.03\end{array}$ & $\begin{array}{c}0.0572^{* * *} \\
2.74\end{array}$ & $\begin{array}{c}0.0335^{* *} \\
2.25\end{array}$ & & & \\
\hline Low Tenure & $\begin{array}{c}-0.0220 \\
-0.73\end{array}$ & $\begin{array}{c}0.0449^{*} \\
1.78\end{array}$ & $\begin{array}{c}0.0229 \\
1.12\end{array}$ & $\begin{array}{c}0.0353 \\
0.85\end{array}$ & $\begin{array}{c}-0.0461 \\
-1.24\end{array}$ & $\begin{array}{c}-0.0108 \\
-0.47\end{array}$ \\
\hline High Tenure & $\begin{array}{c}0.0133 \\
0.46\end{array}$ & $\begin{array}{c}-0.0012 \\
-0.04\end{array}$ & $\begin{array}{c}0.0121 \\
1.14\end{array}$ & & & \\
\hline
\end{tabular}

rates and a low replacement rate for white-collar workers, which results in a substantial long-term decline of $11.82 \%$ in white-collar employment. Evidence shows that buyout investors streamline the administration of the firm after the buyout, especially during the first two years. The shortterm results for managers in Table 5 point in the same direction but are less precisely estimated and statistically not significantly different from those for other employees. The long-term point estimates for managers for all rates reported in Table 6 are low, about half of those for the whole sample, and statistically insignificant. Some evidence exists for an increase in short-term turnover of middle managers, but no evidence emerges for a reduction in the layers of management.

Table 7 shows the individual-level results for managers (Regression 1) and white-collar employees (Regression 2). We observe an economically dramatic decline in long-term Earnings for managers by $29.4 \log$ points $(€ 2,019)$, which is entirely driven by a decline in employment $(-14.4$ $\log$ points or 8.36 days). These effects are statistically 
Table 6

Establishment-level and group-specific employee flows from $t$ to $t+5$.

This table replicates the analysis of Table 4 for specific groups. Rates are calculated over period $t$ to period $t+5$; i.e., growth rates are computed over a six-year period from the end of $t-1$ to the end of $t+5$. All variables are defined in Table 1. Wage terciles (low, medium, high) are based on Daily Wage. High and low splits are based on the median. Columns 1 to 3 report the coefficients $\theta$ from Regression 1 with growth rates (Column 1), separation rates (Column 2) and hiring rates (Column 3) as the dependent variable. Columns 4 to 6 provide tests for differences between groups of employees. In Panel A, the test is for whether these groups are different from their complement, e.g., White Collar minus all non-white-collar employees. In Panel B, the comparison is always for the difference between the highest and lowest quantile, e.g., High Wage minus Low Wage. The number of observations varies per group because observations are missing when the establishment does not have at least one employee of the respective group and one point in time. The maximum number of observations is 24,700 (White Collar), and the minimum number is 11,364 (Manager). Standard errors are clustered at the firm level. $t$-statistics are provided below the coefficient estimates. ${ }^{*},{ }^{* *}$, and ${ }^{* * *}$ indicate significance at the $10 \%, 5 \%$, and $1 \%$ level, respectively.

\begin{tabular}{|c|c|c|c|c|c|c|}
\hline \multicolumn{7}{|c|}{ Panel A: Occupational groups } \\
\hline \multirow[b]{2}{*}{ Group } & \multicolumn{3}{|c|}{ From $t$ to $t+5$} & \multicolumn{3}{|c|}{ Group - all other employees } \\
\hline & $\begin{array}{c}\text { Empl. Growth } \\
\text { Rate }[\theta(g)] \\
\text { (1) }\end{array}$ & $\begin{array}{c}\text { Separation } \\
\text { Rate }[\theta(s)] \\
\text { (2) }\end{array}$ & $\begin{array}{c}\text { Hiring } \\
\text { Rate }[\theta(h)] \\
\text { (3) }\end{array}$ & $\begin{array}{c}\text { Empl. Growth } \\
\text { Rate }[\theta(g)] \\
(4)\end{array}$ & $\begin{array}{c}\text { Separation } \\
\text { Rate }[\theta(s)] \\
\quad(5)\end{array}$ & $\begin{array}{c}\text { Hiring } \\
\text { Rate }[\theta(h)] \\
(6)\end{array}$ \\
\hline White Collar & $\begin{array}{c}-0.1182^{* *} \\
-2.38\end{array}$ & $\begin{array}{c}0.2013^{* * *} \\
3.57\end{array}$ & $\begin{array}{c}0.0831^{* * *} \\
2.17\end{array}$ & $\begin{array}{c}-0.0586 \\
-0.94\end{array}$ & $\begin{array}{c}0.0477 \\
0.64\end{array}$ & $\begin{array}{c}-0.0109 \\
-0.20\end{array}$ \\
\hline Manager & $\begin{array}{c}-0.0266 \\
-0.32\end{array}$ & $\begin{array}{c}0.0809 \\
0.69\end{array}$ & $\begin{array}{c}0.0543 \\
0.97\end{array}$ & $\begin{array}{c}0.0590 \\
0.66\end{array}$ & $\begin{array}{c}-0.1023 \\
-0.81\end{array}$ & $\begin{array}{c}-0.0433 \\
-0.65\end{array}$ \\
\hline IT-Related Job & $\begin{array}{c}-0.0819^{* *} \\
-1.96\end{array}$ & $\begin{array}{c}0.1521^{* * *} \\
2.92\end{array}$ & $\begin{array}{c}0.0702^{* *} \\
2.28\end{array}$ & $\begin{array}{c}0.0002 \\
0.00\end{array}$ & $\begin{array}{c}-0.0701 \\
-0.82\end{array}$ & $\begin{array}{c}-0.0698 \\
-1.15\end{array}$ \\
\hline IT-Integrated Job & $\begin{array}{c}-0.0341 \\
-0.70\end{array}$ & $\begin{array}{c}0.1877^{*} \\
1.94\end{array}$ & $\begin{array}{c}0.1536^{* * *} \\
2.29\end{array}$ & $\begin{array}{c}0.0674 \\
1.08\end{array}$ & $\begin{array}{c}0.0119 \\
0.11\end{array}$ & $\begin{array}{c}0.0793 \\
1.03\end{array}$ \\
\hline
\end{tabular}

Panel B: Group splits

\begin{tabular}{|c|c|c|c|c|c|c|}
\hline \multirow[b]{2}{*}{ Group } & \multicolumn{3}{|c|}{ From $t$ to $t+5$} & \multicolumn{3}{|c|}{ High-low } \\
\hline & $\begin{array}{c}\text { Empl. Growth } \\
\text { Rate }[\theta(g)] \\
\text { (1) }\end{array}$ & $\begin{array}{l}\text { Separation } \\
\text { Rate }[\theta(s)] \\
\quad(2)\end{array}$ & $\begin{array}{c}\text { Hiring } \\
\text { Rate }[\theta(h)] \\
\text { (3) }\end{array}$ & $\begin{array}{c}\text { Empl. Growth } \\
\text { Rate }[\theta(g)] \\
\text { (4) }\end{array}$ & $\begin{array}{l}\text { Separation } \\
\text { Rate }[\theta(s)] \\
\text { (5) }\end{array}$ & $\begin{array}{c}\text { Hiring } \\
\text { Rate }[\theta(h)] \\
\quad(6)\end{array}$ \\
\hline Low Wage & $\begin{array}{c}-0.1276^{* * *} \\
-2.95\end{array}$ & $\begin{array}{c}0.3393^{* * *} \\
4.57\end{array}$ & $\begin{array}{c}0.2117^{* * * *} \\
2.63\end{array}$ & $\begin{array}{c}0.0660 \\
1.00\end{array}$ & $\begin{array}{c}-0.2128^{* *} \\
-2.43\end{array}$ & $\begin{array}{c}-0.1468^{*} \\
-1.73\end{array}$ \\
\hline Medium Wage & $\begin{array}{c}-0.0949^{*} \\
-1.92\end{array}$ & $\begin{array}{c}0.0449^{* * *} \\
3.49\end{array}$ & $\begin{array}{c}0.0211^{* * *} \\
2.89\end{array}$ & & & \\
\hline High Wage & $\begin{array}{c}-0.0616 \\
-1.23\end{array}$ & $\begin{array}{c}0.1265^{* * * *} \\
2.73\end{array}$ & $\begin{array}{c}0.0649^{* *} \\
2.38\end{array}$ & & & \\
\hline Low Routine Job & $\begin{array}{c}-0.0977^{* *} \\
-2.24\end{array}$ & $\begin{array}{l}0.1979^{* * *} \\
\quad 3.96\end{array}$ & $\begin{array}{l}0.1002^{* * *} \\
2.79\end{array}$ & $\begin{array}{c}0.0335 \\
0.56\end{array}$ & $\begin{array}{c}-0.0651 \\
-0.99\end{array}$ & $\begin{array}{c}-0.0316 \\
-0.68\end{array}$ \\
\hline High Routine Job & $\begin{array}{c}-0.0642 \\
-1.59\end{array}$ & $\begin{array}{l}0.1328^{* * *} \\
\quad 3.09\end{array}$ & $\begin{array}{c}0.0686^{* *} \\
2.31\end{array}$ & & & \\
\hline Low Offshorable Job & $\begin{array}{c}-0.0934^{* *} \\
-2.26\end{array}$ & $\begin{array}{c}0.2079 * * * \\
3.89\end{array}$ & $\begin{array}{c}0.1145^{* * *} \\
2.86\end{array}$ & $\begin{array}{c}0.0342 \\
0.55\end{array}$ & $\begin{array}{c}-0.0900 \\
-1.30\end{array}$ & $\begin{array}{c}-0.0558 \\
-1.11\end{array}$ \\
\hline High Offshorable Job & $\begin{array}{c}-0.0592 \\
-1.29\end{array}$ & $\begin{array}{c}0.1179 * * * \\
2.68\end{array}$ & $\begin{array}{c}0.0587^{*} \\
1.94\end{array}$ & & & \\
\hline Young & $\begin{array}{c}-0.0757^{* *} \\
-2.06\end{array}$ & $\begin{array}{c}0.1705^{* * *} \\
\quad 3.60\end{array}$ & $\begin{array}{c}0.0948^{* *} \\
2.17\end{array}$ & $\begin{array}{c}-0.0157 \\
-0.29\end{array}$ & $\begin{array}{c}-0.0030 \\
-0.05\end{array}$ & $\begin{array}{c}-0.0187 \\
-0.38\end{array}$ \\
\hline Old & $\begin{array}{c}-0.0914^{* *} \\
-2.36\end{array}$ & $\begin{array}{c}0.1675^{* * *} \\
\quad 4.00\end{array}$ & $\begin{array}{c}0.0761^{* * *} \\
3.33\end{array}$ & & & \\
\hline Low Tenure & $\begin{array}{c}-0.1140^{* * *} \\
-2.62\end{array}$ & $\begin{array}{l}0.2069^{* * * *} \\
3.74\end{array}$ & $\begin{array}{c}0.0929^{*} \\
1.74\end{array}$ & $\begin{array}{c}0.1195^{*} \\
1.94\end{array}$ & $\begin{array}{c}-0.1950^{* * *} \\
-2.82\end{array}$ & $\begin{array}{c}-0.0755 \\
-1.38\end{array}$ \\
\hline High Tenure & $\begin{array}{c}0.0055 \\
0.13\end{array}$ & $\begin{array}{c}0.0119 \\
0.29\end{array}$ & $\begin{array}{c}0.0174 \\
1.41\end{array}$ & & & \\
\hline
\end{tabular}

significant. The post-buyout experience of white-collar workers is also negative, with a long-term employment decline of $8.0 \mathrm{log}$ points (5.4 days) and a weakly significant long-term decline in earnings by $€ 702$. We conclude that the adverse implications for managers and whitecollar workers after buyouts are severe and significantly worse than those for other target employees. The shortterm establishment-level results provide some evidence for a reduction in administrative staff, but not for a reduction in the layers of management. We suggest that the negative individual-level results for managers should be attributed to the greater difficulties they experience in finding new employment, probably from a stigma associated with losing their jobs at the target.

\subsection{Technological modernization}

This section investigates the technologicalmodernization argument. Technological change can be beneficial for employees if their skills are complementary 
Table 7

Individual-level analyses of employee characteristics.

The table presents ordinary least squares regressions of Earnings, Daily Wage, and Days Employed in a triple-difference setup from Eq. (3). The dependent variables are in logarithms in Columns 2, 4, and 6. Each specification includes a risk factor, which is measured in the year prior to the buyout announcement. We only report the estimates of $\eta_{2}$ and $\eta_{5}$. In Panel $\mathrm{A}$, the risk factors are Manager (Regression 1) and White Collar (Regression 2). In Panel B, we analyze wages by entering two risk factors in Eq. (3), Low Wage and Medium Wage, which denote the first and second tercile of Daily Wage, respectively. In Panel C, the risk factors are Routine Job (Regression 1) and Offshorable Job (Regression 2). In Panel D, the risk factors are IT-Related Job and IT-Integrated Job. In Panel E, the risk factors are Old (Regression 1), an indicator set equal to one if an employee's age is above the median sample age, and High Tenure (Regression 2 ), an indicator set equal to one if an employee's Firm Tenure is above the sample median. The numerical variables are defined in Table 1, and the categorical variables are defined in Table 3. Each specification contains individual and year fixed effects. The number of observations for Earnings and Days Employed is 2,128,798 = 152,057 target employees $\times 2$ (control employees) $\times 7$ (event-years). The number of observations for Daily Wage is 1,929,354. Standard errors are clustered at the firm level. $t$-statistics are provided below the coefficient estimates. ${ }^{*}, * *$, and ${ }^{* * *}$ indicate significance at the $10 \%, 5 \%$, and $1 \%$ level, respectively.

\begin{tabular}{|c|c|c|c|c|c|c|}
\hline \multirow[b]{2}{*}{ Independent variable } & \multicolumn{6}{|c|}{ Dependent variable } \\
\hline & $\begin{array}{l}\text { Earnings } \\
\text { (euro) } \\
\text { (1) }\end{array}$ & $\begin{array}{l}\text { Earnings } \\
\quad(\ln ) \\
(2)\end{array}$ & $\begin{array}{l}\text { Daily Wage } \\
\text { (euro) } \\
\text { (3) }\end{array}$ & $\begin{array}{l}\text { Daily Wage } \\
\quad(\ln ) \\
\quad(4)\end{array}$ & $\begin{array}{l}\text { Days Empl. } \\
\text { (days) } \\
\text { (5) }\end{array}$ & $\begin{array}{l}\text { Days Empl. } \\
\quad(\ln ) \\
\quad(6)\end{array}$ \\
\hline \multicolumn{7}{|c|}{ Panel A: Organizational streamlining } \\
\hline$D_{i 2} \times$ Target $\times$ Manager & $\begin{array}{c}-965.67^{*} \\
-1.76\end{array}$ & $\begin{array}{l}-0.071 \\
-0.97\end{array}$ & $\begin{array}{l}-0.81 \\
-0.80\end{array}$ & $\begin{array}{c}-0.007 \\
-0.82\end{array}$ & $\begin{array}{l}-2.38 \\
-0.88\end{array}$ & $\begin{array}{l}-0.028 \\
-0.70\end{array}$ \\
\hline$D_{i 5} \times$ Target $\times$ Manager & $\begin{array}{c}-2019.40^{* * *} \\
-2.59\end{array}$ & $\begin{array}{c}-0.294^{* *} \\
-2.36\end{array}$ & $\begin{array}{l}-0.32 \\
-0.36\end{array}$ & $\begin{array}{l}-0.006 \\
-0.61\end{array}$ & $\begin{array}{l}-8.36^{*} \\
-1.91\end{array}$ & $\begin{array}{c}-0.144^{* *} \\
-2.12\end{array}$ \\
\hline \multicolumn{7}{|c|}{ Regression 2: White-collar employees versus all others } \\
\hline$D_{i 2} \times$ Target $\times$ White Collar & $\begin{array}{c}-455.01^{*} \\
-1.67\end{array}$ & $\begin{array}{c}-0.123^{* * *} \\
-3.11\end{array}$ & $\begin{array}{l}-0.05 \\
-0.09\end{array}$ & $\begin{array}{l}-0.007 \\
-0.94\end{array}$ & $\begin{array}{l}-4.35^{* *} \\
-2.26\end{array}$ & $\begin{array}{c}-0.065^{*} \\
-1.90\end{array}$ \\
\hline$D_{i 5} \times$ Target $\times$ White Collar & $\begin{array}{c}-701.89^{*} \\
-1.95\end{array}$ & $\begin{array}{c}-0.151^{* *} \\
-2.22\end{array}$ & $\begin{array}{l}0.07 \\
0.10\end{array}$ & $\begin{array}{l}-0.010 \\
-0.99\end{array}$ & $\begin{array}{c}-5.40^{* *} \\
-2.16\end{array}$ & $\begin{array}{c}-0.080^{*} \\
-1.73\end{array}$ \\
\hline \multicolumn{7}{|l|}{$\begin{array}{l}\text { Panel B: Technological change } \\
\text { Regression 1: Wage terciles }\end{array}$} \\
\hline$D_{i 2} \times$ Target $\times$ Low Wage & $\begin{array}{c}975.53^{* * * *} \\
2.78\end{array}$ & $\begin{array}{c}0.005 \\
0.09\end{array}$ & $\begin{array}{l}0.92 \\
1.37\end{array}$ & $\begin{array}{c}0.010 \\
1.17\end{array}$ & $\begin{array}{l}1.01 \\
0.39\end{array}$ & $\begin{array}{l}-0.007 \\
-0.16\end{array}$ \\
\hline$D_{i 5} \times$ Target $\times$ Low Wage & $\begin{array}{c}1258.87^{* *} \\
2.01\end{array}$ & $\begin{array}{c}0.018 \\
0.15\end{array}$ & $\begin{array}{c}2.04^{*} \\
1.77\end{array}$ & $\begin{array}{c}0.016 \\
1.35\end{array}$ & $\begin{array}{l}-0.52 \\
-0.13\end{array}$ & $\begin{array}{c}-0.009 \\
-0.13\end{array}$ \\
\hline$D_{i 2} \times$ Target $\times$ Medium Wage & $\begin{array}{c}698.65^{* * * *} \\
2.97\end{array}$ & $\begin{array}{c}0.075^{* *} \\
2.18\end{array}$ & $\begin{array}{l}0.56 \\
0.93\end{array}$ & $\begin{array}{c}0.005 \\
0.92\end{array}$ & $\begin{array}{l}1.71 \\
1.41\end{array}$ & $\begin{array}{c}0.030 \\
1.59\end{array}$ \\
\hline$D_{i 5} \times$ Target $\times$ Medium Wage & $\begin{array}{c}490.58 \\
1.36\end{array}$ & $\begin{array}{c}0.021 \\
0.32\end{array}$ & $\begin{array}{l}0.62 \\
0.74\end{array}$ & $\begin{array}{c}0.005 \\
0.75\end{array}$ & $\begin{array}{l}-0.34 \\
-0.15\end{array}$ & $\begin{array}{c}0.002 \\
0.06\end{array}$ \\
\hline \multicolumn{7}{|c|}{$\begin{array}{l}\text { Panel C: Routinization and offshorability } \\
\text { Regression 1: Employees with a routine job versus all others }\end{array}$} \\
\hline $\begin{array}{l}\text { Regression } 1 \text { : Employees with } \\
D_{i 2} \times \text { Target } \times \text { Routine Job }\end{array}$ & $\begin{array}{c}459.79^{* *} \\
2.27\end{array}$ & $\begin{array}{c}0.053^{*} \\
1.93\end{array}$ & $\begin{array}{l}-0.08 \\
-0.15\end{array}$ & $\begin{array}{c}-0.002 \\
-0.30\end{array}$ & $\begin{array}{c}2.57^{*} \\
1.93\end{array}$ & $\begin{array}{c}0.033 \\
1.52\end{array}$ \\
\hline$D_{i 5} \times$ Target $\times$ Routine Job & $\begin{array}{c}586.16^{* *} \\
2.09\end{array}$ & $\begin{array}{c}0.067 \\
1.47\end{array}$ & $\begin{array}{l}-0.12 \\
-0.20\end{array}$ & $\begin{array}{l}-0.003 \\
-0.32\end{array}$ & $\begin{array}{l}2.30 \\
1.33\end{array}$ & $\begin{array}{c}0.030 \\
1.00\end{array}$ \\
\hline \multicolumn{7}{|c|}{ Regression 2: Employees with an offshorable job versus all others } \\
\hline$D_{i 2} \times$ Target $\times$ Offshorable Job & $\begin{array}{c}-229.39 \\
-0.86\end{array}$ & $\begin{array}{c}-0.020 \\
-0.52\end{array}$ & $\begin{array}{l}-0.15 \\
-0.28\end{array}$ & $\begin{array}{c}0.002 \\
0.23\end{array}$ & $\begin{array}{l}-0.57 \\
-0.37\end{array}$ & $\begin{array}{l}-0.009 \\
-0.33\end{array}$ \\
\hline$D_{i 5} \times$ Target $\times$ Offshorable Job & $\begin{array}{c}-50.28 \\
-0.15\end{array}$ & $\begin{array}{c}0.010 \\
0.14\end{array}$ & $\begin{array}{l}0.14 \\
0.20\end{array}$ & $\begin{array}{c}0.001 \\
0.06\end{array}$ & $\begin{array}{l}0.37 \\
0.16\end{array}$ & $\begin{array}{c}0.014 \\
0.34\end{array}$ \\
\hline \multicolumn{7}{|c|}{ Panel D: Information Technology expertise } \\
\hline$D_{i 2} \times$ Target $\times$ IT-Related Job & $\begin{array}{l}-145.44 \\
-0.75\end{array}$ & $\begin{array}{l}-0.045 \\
-1.56\end{array}$ & $\begin{array}{l}0.25 \\
0.54\end{array}$ & $\begin{array}{l}-0.004 \\
-0.64\end{array}$ & $\begin{array}{l}-1.95 \\
-1.28\end{array}$ & $\begin{array}{l}-0.023 \\
-0.97\end{array}$ \\
\hline$D_{i 5} \times$ Target $\times$ IT-Related Job & $\begin{array}{l}-280.20 \\
-1.03\end{array}$ & $\begin{array}{c}-0.018 \\
-0.36\end{array}$ & $\begin{array}{l}-0.06 \\
-0.10\end{array}$ & $\begin{array}{l}-0.008 \\
-1.13\end{array}$ & $\begin{array}{l}-1.07 \\
-0.56\end{array}$ & $\begin{array}{c}-0.006 \\
-0.19\end{array}$ \\
\hline \multicolumn{7}{|c|}{ Regression 2: Employees in jobs with above-median use of IT-integrated tools } \\
\hline$D_{i 2} \times$ Target $\times$ IT-Integrated Job & $\begin{array}{c}286.75 \\
1.30\end{array}$ & $\begin{array}{c}0.034 \\
1.09\end{array}$ & $\begin{array}{l}0.26 \\
0.55\end{array}$ & $\begin{array}{c}0.005 \\
0.78\end{array}$ & $\begin{array}{l}1.16 \\
0.89\end{array}$ & $\begin{array}{c}0.009 \\
0.45\end{array}$ \\
\hline$D_{i 5} \times$ Target $\times$ IT-Integrated Job & $\begin{array}{c}175.55 \\
0.54\end{array}$ & $\begin{array}{c}0.031 \\
0.53\end{array}$ & $\begin{array}{l}-0.10 \\
-0.18\end{array}$ & $\begin{array}{c}0.005 \\
0.66\end{array}$ & $\begin{array}{l}1.35 \\
0.64\end{array}$ & $\begin{array}{c}0.018 \\
0.54\end{array}$ \\
\hline \multicolumn{7}{|c|}{ Panel E: Transfer of wealth } \\
\hline$D_{i 2} \times$ Target $\times$ Old & $\begin{array}{l}-696.40^{* * * *} \\
-3.92\end{array}$ & $\begin{array}{l}-0.098^{* * *} \\
-3.21\end{array}$ & $\begin{array}{c}-0.73^{* *} \\
-2.50\end{array}$ & $\begin{array}{c}-0.008 \\
-1.44\end{array}$ & $\begin{array}{l}-4.00^{* * *} \\
-3.17\end{array}$ & $\begin{array}{l}-0.050^{* *} \\
-2.53\end{array}$ \\
\hline$D_{i 5} \times$ Target $\times$ Old & $\begin{array}{l}-807.04^{* *} \\
-2.44\end{array}$ & $\begin{array}{l}-0.184^{* * *} \\
-2.61\end{array}$ & $\begin{array}{l}-1.15^{* * *} \\
-2.61\end{array}$ & $\begin{array}{l}-0.018^{* *} \\
-2.10\end{array}$ & $\begin{array}{l}-6.19^{* *} \\
-2.54\end{array}$ & $\begin{array}{l}-0.106^{* * *} \\
-2.71\end{array}$ \\
\hline Regression 2: Employees with & ve-median firn & hure versus & thers & & & \\
\hline$D_{i 2} \times$ Target $\times$ High Tenure & $\begin{array}{c}-127.26 \\
-0.50\end{array}$ & $\begin{array}{c}0.031 \\
0.79\end{array}$ & $\begin{array}{l}-0.30 \\
-0.57\end{array}$ & $\begin{array}{l}-0.002 \\
-0.38\end{array}$ & $\begin{array}{l}0.35 \\
0.20\end{array}$ & $\begin{array}{c}0.019 \\
0.68\end{array}$ \\
\hline$D_{i 5} \times$ Target $\times$ High Tenure & $\begin{array}{l}-413.22 \\
-0.94\end{array}$ & $\begin{array}{l}-0.019 \\
-0.20\end{array}$ & $\begin{array}{l}-1.05 \\
-1.34\end{array}$ & $\begin{array}{l}-0.009 \\
-1.02\end{array}$ & $\begin{array}{l}-1.14 \\
-0.35\end{array}$ & $\begin{array}{l}-0.014 \\
-0.26\end{array}$ \\
\hline
\end{tabular}


to the new technology. Then, employees become more productive. A new technology can also have negative effects if it substitutes for employees' skills and depreciates their human capital. The technological change argument relies on this notion of technology skills complementarity and, therefore, does not make general predictions on how employees should be affected by technological change and how PE buyouts that foster technological change should affect employees. Instead, different types of technological change can affect employees differently. The recent literature sees $\mathrm{PE}$ buyouts as vehicles that raise investment in information technology (Agrawal and Tambe, 2016) or overcome firms' resistance to adapt to trends, such as skill-biased technological change, offshoring and routinization of jobs, which in turn lead to job polarization (Olsson and Tåg, 2017). In this section, we analyze whether these trends can explain the overall results we show in Section 3 for employment and wages.

The skill-biased technological change hypothesis attributes the rising wage inequality in industrialized countries to technological progress, which has benefited highskilled workers, whose skills are complementary to new technologies, but caused a relative reduction in wages for low-skilled workers (see Katz and Autor (1999) for a survey). If private equity firms overcome resistance to this trend, then the costs of PE buyouts can fall disproportionately on employees with lower education and skill levels, whose wages and employment fall relative to employees with higher education and skill levels.

We use pre-buyout wage levels to stratify employees in Tables 5-7. We divide all employees who are employed for the full year evenly into terciles according to Daily Wage: the lowest (medium, highest) income tercile is labeled as low (medium, high) wage. With this classification, we have two risk factors in Eq. (3), one for Low Wage and one for Medium Wage.

The SBTC hypothesis predicts employment and income should decline for the lowest group. The establishmentlevel results in Tables 5 and 6 are partially consistent with the SBTC hypothesis. The short-term and long-term separation rates for low-wage target employees are higher than those for control employees, and they are statistically and economically much higher compared with highwage employees. These results support the SBTC hypothesis. Most of the increased separations are compensated by more hiring of low-wage employees by buyout targets, and the long-term buyout effect on hiring is higher by $14.68 \%$ and significant at the $10 \%$ level. As a result, the postbuyout employment decline of low-wage employees is only moderately larger, and statistically not distinguishable from that of high-wage employees. Because the SBTC hypothesis predicts that high-wage employees displace low-wage employees, our results offer at best modest support to the hypothesis that buyouts in our sample foster SBTC. Instead of observing the displacement of low-wage employees by high-wage employees, we find higher turnover only within the group of low-wage employees, for which there is no obvious explanation. To explore this question further, we investigate alternative stratifications of employees based on education and a classification of occupational skill lev- els (see Table OA10 in the Online Appendix, Panel A) but cannot find any support for the prediction that the separation (employment growth) rates for low-education or lowskill employees are lower (higher) than those for, respectively, highly educated or high-skill employees.

At the individual employee level, we find that the triple interactions for the short term and the long term $\left(D_{i 2} \times\right.$ Target $\times$ Low Wage and $D_{i 5} \times$ Target $\times$ Low Wage $)$ both show a significant and positive employment change for low-wage target employees if we measure Earnings in euros. All other results in Table 7 are statistically insignificant, except for one coefficient for Daily Wage, which has the wrong sign. Hence, we cannot find support for the SBTC hypothesis at the individual level, probably because low-wage employees find it easy to find new employment after separations from the target.

More recent research notes inconsistencies between the SBTC hypothesis and developments in labor markets (e.g., Card and DiNardo (2002); Goos et al., 2014; Mishel et al., 2013). Instead, some studies observe that employment shares rise in the highest-wage and lowest-wage occupations, at the expense of mid-level occupations (e.g., Goos and Manning, 2007), a pattern described as job polarization. The reason for this development is seen in the fact that low-wage manual jobs (e.g., health workers, janitors, security guards) are more difficult to replace with computerized technologies or cannot be outsourced to countries with lower labor costs (offshorable jobs). Medium-skilled workers who perform routine tasks can see their jobs replaced by technology or outsourced to low-wage countries (e.g., Blinder, 2009; Blinder and Krueger, 2009).

Following Olsson and Tåg (2017), we hypothesize that PE buyouts overcome resistance to offshoring and routinization and ask whether employees with routine or offshorable jobs fare worse after buyouts. ${ }^{14}$ We apply the definitions of Goos et al. (2014) to categorize jobs as routine or offshorable. ${ }^{15}$ At the individual level, we find positive effects and, hence, the opposite of the predicted signs, which are statistically significant for the association of routinization with Earnings and Days Employed. All other effects are statistically insignificant (Table 7). The establishment-level analyses corroborate these findings (Tables 5 and 6). The long-term separation and growth rates are numerically higher but statistically indistinguishable for employees with less routinized and offshorable jobs. Thus, the analyses neither at the individual nor at the establishment level offer supporting evidence for the prediction that buyouts foster offshoring and routinization, and there is even some evidence to the contrary.

Job polarization predicts negative developments for the medium stratum of the labor market relative to the other groups. We can check if the results for the medium-wage employees conform to the predictions of

\footnotetext{
14 Offshoring is, strictly speaking, not a technology, but the literature on job polarization relates the offshorability of jobs to their technological aspects and skill requirements, so we discuss offshorability in this context.

15 We follow the description in the Online Appendix of Goos et al. (2014), which is available at https://assets.aeaweb.org/assets/production/ articles-attachments/aer/app/10408/20111536_app.pdf.
} 
the job-polarization hypothesis. The individual-level analysis shows that the triple interactions for these groups have mostly positive signs, although only two are statistically significant at the $10 \%$ level (Table 7 , Panel B). Establishment-level results are consistent with this result as separation and hiring rates are higher for low-wage employees than for medium-wage employees, although the differences between medium-wage and either high-wage or low-wage employees are never statistically significant. Our results offer no support for the job polarization hypothesis.

Agrawal and Tambe (2016) argue that PE buyouts foster the investments in IT and the implementation of IT-based technologies. Based on their analysis, we expect that target employees with more IT exposure become more valuable after the buyout and that their wages and employment increases compared with the control group. To investigate this question, we obtain access to IAB data about job classifications based on the tools each job requires (Genz et al., 2019). Tools are categorized into three categories as IT-Integrated Tools, defined as tools "that are electronically based or supported and that are explicitly dedicated to an industry 4.0 or services 4.0 feature, such as 3D printers, machine learning software or mobile robots," IT-Aided Tools, which "are electronically based or supported, such as computers, printers, electronic machines" but not classified as IT-integrated, and Non-IT Tools (Genz et al., 2019, p. 5). Genz et al. (2019) then establish the proportion of tools that can be classified as IT-integrated or IT-aided used in each occupation. Higher scores on the IT-aided tools index describe jobs with a broad skill set, and higher scores on the IT-integrated tools index describe jobs with higher skill requirements. We use these proportions and say that all employees who have a job with an abovemedian score of the sum of IT-aided and IT-integrated tools as having an IT-Related Job. Far fewer employees use IT-integrated tools, so the median of this score is zero. We say an employee has an IT-Integrated job if at least one of the tools used in that job is IT-integrated. Both variables describe jobs with significant exposure to computerized technologies.

We use the classification of jobs as IT-related and non-IT-related, respectively, as IT-integrated and non-ITintegrated and repeat the analyses for this sample split. The point estimates for long-term hiring rates and net employment growth in Table 6 suggest that buyout firms hire more IT-integrated and IT-related workers and that net employment growth is larger for the former group compared with all other employees, but the estimates are too imprecise to be statistically significant. Short-term net employment growth is statistically significantly higher (10\% level) for IT-integrated jobs. Panel D of Table 7 reports the individual-level results, all of which are insignificant. Target employees who use IT tools, defined narrowly or more broadly, do not have different wages or employment levels after buyouts compared with a matched control group and compared with non-IT employees. We observe additional hiring and job growth for IT-integrated jobs, consistent with prior literature, but no effect on the human capital of the affected employees.

\subsection{Transfers of wealth}

A long-standing debate on buyouts and the activity of private equity firms is whether they create shareholder value primarily through transfers of wealth (see the discussion at the beginning of the Introduction) or whether the adverse consequences for employees should be seen as a side effect of a process of modernization and creative destruction (Kaplan, 1989; Davis et al., 2014). In this section, we try to shed some light on this discussion. Empirically, distinguishing between intended effects and side effects is impossible. Hence, we analyze more specific processes associated with the transfer-of-wealth mechanism.

The transfer-of-wealth argument was articulated most clearly by Shleifer and Summers (1988), who argue that firms offer long-term employment insurance to employees. Employees rely on managers and owners to honor these unwritten agreements, which are credible, e.g., because managers and owners pass through loyalty filters (Akerlof, 1983) in their career that align their preferences with those of the employees. A change in ownership can undermine the commitment to such implicit contracts if the new owners do not feel bound by agreements the previous owners entered into with the employees.

The literature has two different arguments on transfers of wealth, both of which build on the notion of implicit contracts. The first relies on risk sharing within firms, and the second relies on firm-specific human capital. Because these arguments have different implications for employment and wages, we develop and test them separately.

\subsubsection{Risk sharing and dynamic wage contracts}

According to the risk-sharing argument, firms provide employment and wage insurance to employees in exchange for lower wages (Azariadis, 1975; Baily 1974). The dynamic version of this argument implies that wage profiles are rising with employees' age. Insurance implies that wages cannot be cut when productivity falls, but voluntary employment implies that wages increase when productivity rises, resulting in a ratchet effect (Harris and Holmstrom, 1982). Wages can then rise in excess of employees' marginal productivity toward the end of their careers, and they can rise above employees' productivity. Firms extract expected rents, e.g., through lower wages, at the beginning of employment relations (Ray, 2002). A similar argument follows from Lazear (1979), who develops a model in which firms elicit unobservable effort in exchange for rising wage profiles. If the new owners after PE buyouts would renege on these implicit agreements, they would lay off or cut the wages of older employees.

In Regression 1 of Table 7, Panel E, we use Age as a risk factor and split the sample at the median age of all employees (42 years). We find statistically and economically strong effects. The long-term decline of Earnings of older buyout employees is larger by $18.4 \mathrm{log}$ points, or $€ 807$ ( $2.3 \%$ of the median wage), compared with older control employees or with younger target employees. Unlike for other groups of employees, we observe a significantly negative wage effect for older employees, which compounds the negative employment effect. 
Next, we investigate whether older employees of PE targets experience higher separation rates after buyouts. The theoretical argument implies that PE buyers replace older employees who earn above their productivity with younger employees, who earn less. Such a policy would result in higher post-buyout separation rates for older target employees compared with control employees and higher postbuyout hiring rates for younger employees. Tables 5 and 6 show that this is not the case. The long-term post-buyout separation rate is even slightly higher for younger target employees compared with older target employees, although this difference is almost zero. The difference for hiring rates has the predicted sign (young: 9.48\%; old: $7.61 \%$ ) but is small and statistically insignificant. Hence, the human resource policies of private equity investors do not appear to be biased against older employees. In all likelihood, the negative individual-level results for older employees should be attributed to older employees not finding new employment after losing employment at the target firm. We could cast the discussion of dynamic wage profiles in terms of tenure with the firm instead of age, but the discussion in Section 4.4.2 shows that this would not affect our conclusions.

\subsubsection{Firm-specific human capital}

Shleifer and Summers (1988) formulate a different version of the transfer-of-wealth argument. They hypothesize that firms offer long-term employment protection to employees to provide incentives for investments in firmspecific human capital. New owners can abrogate these contracts and take advantage of employees with firmspecific human capital by forcing them to accept lower wages. The two testable implications of this hypothesis are that (1) PE buyouts lead to a reduction in wages for employees who continue to be employed by the target firm (see Rosett (1990) and Gokhale et al. (1995) for tests of a related argument on takeovers) and that (2) these wage cuts fall disproportionately on employees with more firmspecific human capital.

We test the first implication, i.e., the reduction of wages for continuing employees, by performing a triple-difference analysis at the individual level. We add interaction effects with the dummy variable Leaver, which equals one for employees who leave their establishment between the end of year $t-1$ and the end of year $t+5$. We provide the results for the overall sample and for some of the pertinent subgroups of employees in Table 8. Table OA11 in the Online Appendix provides the same results for the shorter period from $t-1$ to $t+2$. Baseline growth rates of Earnings and Daily Wage are consistently positive, and Days Employed declines by 2.7 days per year. Most importantly, changes for all three variables for target employees (interaction Target $_{i} \times D_{i 5}$ ) in the whole sample, and for almost all subgroups, are economically and statistically indistinguishable from zero. The exception are employees in the lowest wage tercile, who experience an increase in Earnings ( $€$ 440). Employees who stay with their establishments after PE buyouts do not lose, neither in absolute terms nor in relative terms, compared with employees of non-PE targets, which is inconsistent with the specific-human capital argument. Employees who leave the firm (interaction $D_{i 5} \times$ Leaver $_{i}$ ) lose substantially in terms of Earnings. This negative effect on leaving employees is exacerbated for target employees, and the triple interaction effect is significant for all seven groups of employees in Panel B of Table 8. The results are quantitatively strongest for employees in the highest wage tercile and for managers.

To address the specific human capital argument more directly, we follow the literature (e.g., Poletaev and Robinson, 2008) and measure the specificity of human capital by individuals' tenure in their current job. We use the median tenure in our sample to distinguish between high and low tenure. Regression 2 in Table 7, Panel E, presents the individual-level results. None of the coefficients is significant, suggesting that the specificity of human capital cannot explain the differences for employment and earnings of buyout employees compared with control employees. For the establishment-level results in Table 6, the longterm separation rate for low-tenure employees is $20.69 \%$ compared with only $1.19 \%$ for high-tenure employees, and the difference is significant at the $1 \%$ level. These results are consistent with a special protection of high-tenure employees, which is implied by insider-outsider theories (see Lindbeck and Snower, 1986; Lindbeck and Snower, 1988) that build on the notion that insiders are more entrenched than outsiders, an arrangement that is apparently immune to private equity interventions.

To summarize, we cannot find support for any of the implications of the transfer-of-wealth view we can test. No evidence emerges that PE targets extract quasi-rents from older employees by laying them off at a higher rate than younger employees. Also, no evidence shows that PE buyouts benefit from the lock-in of employees with more firmspecific human capital through lower wages, or at least through lower wage growth. We are careful to add that we test specific versions of the transfer-of-wealth argument. The losses of employment and earnings we show can still involve some breach of implicit employment contracts, which are not observable. We can test only specific implications and not the broader questions of whether PE buyers sever any implicit long-term employment guarantees.

\section{Discussion and conclusion}

We study the development of employment and wages of a large sample of German employees whose firms were acquired by private equity firms. Buyouts are followed by a decline in employment and an increase in employee turnover. Increases in separation and hiring rates are strongly correlated across transactions and across the groups of employees we study. Individual-level earnings of buyout employees fall by $€ 980$ five years after the buyout, which amounts to about $2.8 \%$ of median earnings.

When we analyze groups of employees with particular characteristics, establishment-level results and individuallevel results often point in different directions. For example, employees in the lowest wage tercile and those with below-median tenure at the firm experience a higher incidence of separations from the target after buyouts. These 
Table 8

Individual-level analyses of stayers and leavers.

The table presents ordinary least squares regressions of Earnings, Daily Wage, and Days Employed in a triple-difference setup from Eq. (3). Each specification includes an indicator variable Leaver, which is one if the employee leaves the target establishment at some point between $t$ and $t+5$. We only report the estimates of $\gamma_{5}, \theta_{5}, \lambda_{5}$, and $\eta_{5}$. In Panel A, we report the results for regressions of Earnings, Daily Wage, and Days Employed and their logarithmic transformations for the whole sample. In Panel B, we report the results for regressions of Earnings for subsamples of employees. The numerical variables are defined in Table 1, and the categorical variables are defined in Table 3. Low Wage and High Wage denote the first and third tercile of Daily Wage, respectively. Each specification includes individual and year fixed effects. Standard errors are clustered at the firm level. $t$-statistics are provided below the coefficient estimates. ${ }^{*},{ }^{* *}$, and ${ }^{* * *}$ indicate significance at the $10 \%, 5 \%$, and $1 \%$ level, respectively.

Panel A: Full sample

Dependent variable

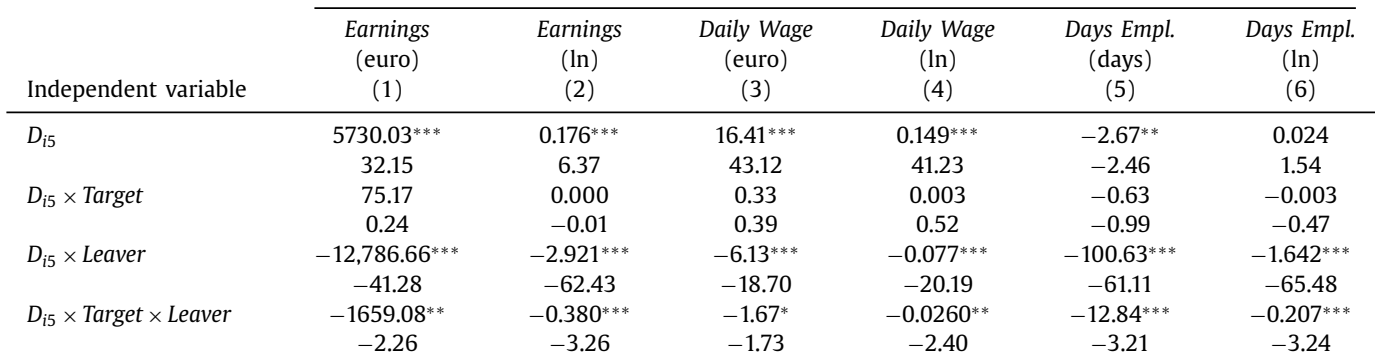

Panel B: Subsamples, dependent variable: Earnings (euro)

\begin{tabular}{|c|c|c|c|c|c|c|}
\hline \multirow[b]{2}{*}{ Independent variable } & \multicolumn{6}{|c|}{ Subsample } \\
\hline & $\begin{array}{c}\text { White } \\
\text { Collar } \\
(1)\end{array}$ & $\begin{array}{c}\text { Manager } \\
\text { (2) }\end{array}$ & $\begin{array}{l}\text { Young } \\
(3)\end{array}$ & $\begin{array}{l}\text { Old } \\
(4)\end{array}$ & $\begin{array}{l}\text { Low } \\
\text { Wage } \\
(5)\end{array}$ & $\begin{array}{c}\text { High } \\
\text { Wage } \\
(6)\end{array}$ \\
\hline$D_{i 5}$ & $\begin{array}{c}6137.76^{* * * *} \\
34.19\end{array}$ & $\begin{array}{c}7301.13^{* * *} \\
13.58\end{array}$ & $\begin{array}{c}4106.66^{* * * *} \\
21.10\end{array}$ & $\begin{array}{c}6944.50^{* * *} \\
42.35\end{array}$ & $\begin{array}{c}4468.62^{* * *} \\
32.19\end{array}$ & $\begin{array}{c}6653.27^{* * * *} \\
24.27\end{array}$ \\
\hline$D_{i 5} \times$ Target & $\begin{array}{c}150.56 \\
0.48\end{array}$ & $\begin{array}{c}-186.21 \\
-0.37\end{array}$ & $\begin{array}{l}11.77 \\
0.04\end{array}$ & $\begin{array}{c}145.27 \\
0.39\end{array}$ & $\begin{array}{c}440.38^{* *} \\
1.97\end{array}$ & $\begin{array}{c}-156.32 \\
-0.32\end{array}$ \\
\hline$D_{i 5} \times$ Leaver & $\begin{array}{c}-11,829.58^{* * *} \\
-44.49\end{array}$ & $\begin{array}{c}-21,631.17^{* * * *} \\
-26.96\end{array}$ & $\begin{array}{c}-20,512.65^{* * *} \\
-46.26\end{array}$ & $\begin{array}{c}-6,348.54^{* * *} \\
-34.13\end{array}$ & $\begin{array}{c}-5,724.72^{* * *} \\
-43.89\end{array}$ & $\begin{array}{c}-20,094.56^{* * *} \\
-31.74\end{array}$ \\
\hline$D_{i 5} \times$ Target $\times$ Leaver & $\begin{array}{c}-2,120.96^{* *} \\
-2.54\end{array}$ & $\begin{array}{c}-3715.67^{* * *} \\
-2.82\end{array}$ & $\begin{array}{c}-1566.16^{*} \\
-1.80\end{array}$ & $\begin{array}{c}-1302.55^{* *} \\
-2.54\end{array}$ & $\begin{array}{c}-1213.44^{* * *} \\
-2.93\end{array}$ & $\begin{array}{c}-2764.20^{* *} \\
-2.44\end{array}$ \\
\hline Number of observations & 609,504 & 57,190 & $1,024,373$ & $1,104,425$ & 709,499 & 709,597 \\
\hline
\end{tabular}

characteristics do not predict individual-level unemployment and losses to employees' long-term earnings. Managers and older employees experience large losses after buyouts, even though they do not experience higher separations from the target compared with other employees. The employees who lose most after buyouts are those who seem to find it harder to find new employment, not those who experience a higher incidence of job loss after buyouts. We infer that buyout investors replace employees based on characteristics such as ability, which are observable to managers after buyouts but not reflected in the employee characteristics in our data.

We find only limited evidence for theories that predict changes in the composition of the workforce after buyouts. Some evidence shows that a disproportionate part of the decline in employment falls on white-collar workers, pointing to the creation of leaner firms through laying off administrative staff. Similarly, some evidence shows net employment growth in jobs that require more IT skills. Other theories that propose changes in the composition of the workforce, e.g., those related to particular forms of technological change, have little or no explanatory power. We conclude that the first-order effects after buyouts are changes in the size and quality of the workforce, not a change in its overall composition.

\section{Appendix A}

This Appendix provides more detailed information about the record-linkage process (Section A.1), the construction of some of the more complex variables (Section A.2), and the computation of growth rates, hiring rates, and separation rates (Section A.3).

\section{A.1. Record linkage and clustering}

We link establishments to transactions based on company names, because no common company identifiers exist that would easily link our PE buyout sample to the Establishment History Panel. The BHP contains all establishments in Germany with at least one dependent employee at the reference date, June 30 , of the respective year. We are using record linkage techniques (see Herzog et al., 2007) for the purpose of name-based matching using establishment names. ${ }^{16}$ Establishment names consist of the company name, the legal form, and additional information. In principle, the linkage techniques create two standardized variables containing the company name and the firm's

\footnotetext{
${ }^{16}$ The record linkage was performed using methods developed by the German Record Linkage Center (GRLC; see http://www.record-linkage.de).
} 
legal form of incorporation for all data sets that need to be linked. Based on these variables, we perform a record linkage that includes the handling of exceptional cases such as very common firm names or stand-alone establishments. In-sample tests suggest that this procedure is very accurate. $^{17}$

The BHP represents the highest level of aggregation of IAB data. The IAB does not provide data on the firm level and does not track ownership or relations among establishments. To cluster standard errors at the firm level, we apply the record linkage techniques by Herzog et al. (2007) to generate a synthetic firm identifier from the universe of all establishments existing in IAB's data in our observation period. For the target establishments, we use the initial record linkage of company names to establishments, i.e., we group the 2420 establishments into 682 firm-level clusters. This approach yields more clusters than deals because some deals involve several legally distinct companies (e.g., multiple subsidiaries). Subsidiaries often have distinct human resource policies and should, therefore, be treated separately. ${ }^{18}$ Nevertheless, we alternatively build clusters based on deals, i.e., we group the 2420 establishments into 511 deal-level clusters. We rerun our key analyses in Tables 4-7 using deal-level clustering (cf. Table OA12 in the Online Appendix). Standard errors never increase by more than $5 \%$ for any relevant coefficient, and statistical significance remains unchanged.

\section{A.2. Variable construction}

Most variables in our analyses are derived from the Integrated Employment Biographies database. The IEB contains every dependent employee in Germany, i.e., all regular employees since 1975 in West Germany and since 1992 in East Germany as well as all marginally employed workers since $1999 .{ }^{19}$ The data are structured in terms of spells, i.e., employment relations, and the data source reports starting and ending dates of these spells on a daily basis. If employment relations continue into the following calendar year, a notification is given by the employer at the end of each year. The continued employment relation is represented by a new spell in the following calendar year. For categorical variables such as education, qualification, and establishment affiliation, we use the information from the latest spell in a calendar year. All variables except nationality and gender are time-varying and can change for the same individual during the observation period. Numerical variables such as Earnings, Daily Wage, and Days Employed are computed over both the full calendar year

\footnotetext{
17 See Schäffler (2014) and Schild (2016) for a detailed description of the methods and data sources used to perform very similar linkages with IAB's administrative establishment data. They demonstrate that the methods we use are effective in linking IAB's establishment data with external company-level data.

18 A prominent example is Eurowings, a budget airline and whollyowned subsidiary of Lufthansa, which offers lower pay to pilots and flight attendants.

19 The IEB does not cover civil servants and the self-employed. These groups are irrelevant for the companies in our sample. For more details on the sources and structure of IAB's administrative data, see Antoni et al. (2016).
}

and all spells in the respective calendar year, regardless of whether the spells refer to different employers or the same employer. Earnings are top-coded, because wages above a threshold ranging from $€ 51,000$ in 1998 to $€$ 70,000 in 2013 are exempt from certain social security contributions. Maximum Earnings reported in the data can nevertheless be higher because some individuals have more than one job in a given year and social security contributions are calculated for each job, even if the income of all jobs combined exceeds the threshold. Numerical variables such as Age and Tenure are determined on the last day of the calendar year.

The qualification variables presented in Table 3 and used in subsequent analyses are derived from Blossfeld (1987). He classified jobs that are coded according to the German Classification of Occupations 1988 ("Klassifikation der Berufe 1988") into 12 distinct major occupations. Table 1 in Blossfeld (1987, p. 99) provides a detailed overview on those 12 occupations and related International Standard Classification of Occupations (ISCO) codes. In Table 3, we leave out agricultural occupations because our data set does not include individuals from this group, and we merge technicians and engineers into one group.

For our establishment analysis, we aggregate the annualized employment information of individuals at the establishment level. Every calendar year, we sum up or build averages over all employees that were employed at an establishment at the end of the calendar year. Therefore, changes in establishment-level employment are based on changes from December 31 of the previous year to December 31 of the current year.

\section{A.3. Growth rates, separation rates, and hiring rates}

We define $E_{j t}$ as the number of all employees in establishment $j$ at the end of year $t$; $H_{j t}$ as the number of employees who enter establishment $j$ in period $t$, i.e., between the end of year $t-1$ and the end of year $t$; and $S_{j t}$ as the number of employees who are separated from establishment $j$ in period $t$, i.e., between the end of year $t-1$ and the end of year $t$.

We then define employment growth between period $t-1$ and period $t$ as

$g_{j, t-1, t}=\frac{E_{j t}-E_{j, t-1}}{0.5\left(E_{j t}+E_{j, t-1}\right)}$

and observe that

$E_{j t}-E_{j, t-1}=H_{j t}-S_{j t}$

We define one-year hiring rates and separation rates as

$h_{j t}=\frac{H_{j t}}{0.5\left(E_{j t}+E_{j, t-1}\right)}$

and

$s_{j t}=\frac{S_{j t}}{0.5\left(E_{j t}+E_{j, t-1}\right)}$ 
From Eqs. (A.1) and (A.2), we have $g_{j, t-1, t}=h_{j t}-s_{j t}$. We also compute multi-period employment flows as

$$
\begin{aligned}
E_{j, t+k}-E_{j, t-1} & =\sum_{\tau=0}^{\tau=k}\left(E_{j, t+\tau}-E_{j, t+\tau-1}\right)=\sum_{\tau=0}^{\tau=k}\left(H_{j, t+\tau}-S_{j, t+\tau}\right) \\
& =H_{j, t-1, t+\tau}-S_{j, t-1, t+\tau} .
\end{aligned}
$$

Multi-period growth rates between periods $t-1$ and $t+k$ are defined as

$g_{j, t, t+k}=\frac{E_{j, t+k}-E_{j, t-1}}{0.5\left(E_{j, t+k}+E_{j, t-1}\right)}$.

Multi-period hiring rates and separation rates are defined analogously to Eq. (A.6). Generally, $g_{j, t-1, t+k} \neq$ $\sum_{\tau=0}^{\tau=k} g_{j, t+\tau-1, t+\tau}$ and analogously for separation and hiring rates.

\section{References}

Abadie, A., Athey, S., Imbens, G.W., Wooldridge, J., 2017. When Should you Adjust Standard Errors for Clustering?. National Bureau of Economic Research, Cambridge, MA. Unpublished working paper 24003.

Agrawal, A., Tambe, P., 2016. Private equity and workers' career paths: the role of technological change. Rev. Financ. Stud. 29 (9), 2455-2489. doi:10.1093/rfs/hhw025.

Agrawal, A.K., Matsa, D.A., 2013. Labor unemployment risk and corporate financing decisions. J. Financ. Econ. 108 (2), 449-470.

Akerlof, G.A., 1983. Loyalty filters. Am. Econ. Rev. 73 (1), 54-63.

Allard, G.J., 2005. Measuring Job Security Over Time: in Search of a Historical Indicator for EPL (Employment Protection Legislation). Instituto de Empresa Business School, Madrid, Spain. Unpublished working paper WP05-17.

Amess, K., Wright, M., 2007. The wage and employment effects of leveraged buyouts in the UK. Int. J. Econ. Bus. 14 (2), 179-195.

Antoni, M., Ganzer, A., vom Berge, P., 2016. Sample of integrated labour market biographies (SIAB) 1975-2014. FDZ Datenreport 04/2016 (en), Nuremberg, Germany.

Autor, D.H., Dorn, D., 2013. The growth of low-skill service jobs and the polarization of the US labor market. Am. Econ. Rev. 103 (5), 1553-1597.

Autor, D.H., Levy, F., Murnane, R.J., 2003. The skill content of recent technological change: an empirical exploration. Q. J. Econ. 118 (4) 1279-1333.

Azariadis, C., 1975. Implicit contracts and underemployment equilibria. J Political Econ. 83 (6), 1183-1202.

Baily, M.N., 1974. Wages and employment under uncertain demand. Rev. Econ. Stud. 41 (1), 37-50.

Bertrand, M., Mullainathan, S., 2003. Enjoying the quiet life? Corporate governance and managerial preferences. J. Political Econ. 111 (5), 1043-1075.

Blinder, A.S., 2009. Offshoring: big deal, or business as usual?. MIT Press, Boston, MA

Blinder, A.S., Krueger, A.B., 2009. Alternative Measures of Ofshorability: A Survey Approach. National Bureau of Economic Research, Cambrigde, MA. Unpublished working paper 15287.

Blossfeld, H.-P., 1987. Labor-market entry and the sexual segregation of careers in the Federal Republic of Germany. Am. J. Sociol. 93 (1), 89-118.

Boucly, Q., Sraer, D., Thesmar, D., 2011. Growth LBOs. J. Financ. Econ. 102 (2), 432-453.

Brown, J., Matsa, D.A., 2016. Boarding a sinking ship? An investigation of job applications to distressed firms. J. Finance 71 (2), 507-550.

Burbidge, J.B., Magee, L., Robb, A.L., 1988. Alternative transformations to handle extreme values of the dependent variable. J. Am. Stat. Assoc. 83 (401), 123-127.

Card, D., DiNardo, J.E., 2002. Skill-biased technological change and rising wage inequality: some problems and puzzles. J. Labor Econ. 20 (4) 733-783.

Couch, K.A., Placzek, D.W., 2010. Earnings losses of displaced workers revisited. Am. Econ. Rev. 100 (1), 572-589.

Cronqvist, H., Heyman, F., Nilsson, M., Svaleryd, H., Vlachos, J., 2009 Do entrenched managers pay their workers more? J. Finance 64 (1), 309-339.

Davis, S.J., Haltiwanger, J., Handley, K., Jarmin, R., Lerner, J., Miranda, J., 2014. Private equity, jobs, and productivity. Am. Econ. Rev. 104 (12), 3956-3990.
Eckbo, B.E., Thorburn, K.S., 2013. Corporate restructuring. Found. Trends Finance 7 (3), 159-288.

Genz, S., Janser, M., Lehmer, F., 2019. The Impact of Investments in New Digital Technologies on Wages-Worker-Level Evidence from Germany. Institute for Employment Research (IAB), Nuremberg, Germany.. Unpublished working paper.

Gokhale, J., Groshen, E.L., Neumark, D., 1995. Do hostile takeovers reduce extramarginal wage payments? Rev. Econ. Stat. 77 (3), 470-485.

Goos, M., Manning, A., 2007. Lousy and lovely jobs: the rising polarization of work in Britain. Rev. Econ. Stat. 89 (1), 118-133.

Goos, M., Manning, A., Salomons, A., 2014. Explaining job polarization: routine-biased technological change and offshoring. Am. Econ. Rev. 104 (8), 2509-2526.

Graham, J.R., Kim, H., Li, S., Qiu, J., 2013. Human Capital Loss in Corporate Bankruptcy. Duke University, Durham, NC.. Unpublished working paper.

Harris, M., Holmstrom, B., 1982. A theory of wage dynamics. Rev. Econ. Stud. 49 (3), 315-333.

Herzog, T.N., Scheuren, F.J., Winkler, W.E., 2007. Data Quality and Record Linkage Techniques. Springer, New York

Imbens, G., Rubin, D.B., 2015. Causal Inference for Statistics, Social, and Biomedical Sciences: An Introduction. Cambridge University Press, New York.

Imbens, G.W., Wooldridge, J.M., 2009. Recent developments in the econometrics of program evaluation. J. Econ. Lit. 47 (1), 5-86.

ITUC, 2007. Where The House Always Wins: Private Equity, Hedge Funds, and the New Casino Capitalism. International Trade Union Confederation (ITUC), Brussels, Belgium.

Jacobson, L.S., LaLonde, R.J., Sullivan, D.G., 1993. Earnings losses of displaced workers. Am. Econ. Rev. 83 (4), 685-709.

Jensen, M.C., 1989. Eclipse of the public corporation. Harv. Bus. Rev. 67 (5), 61-74.

Kaplan, S., 1989. The effects of management buyouts on operating performance and value. J. Financ. Econ. 24 (2), 217-254.

Kaplan, S.N., Stromberg, P.J., 2009. Leveraged buyouts and private equity. J. Econ. Perspect. 23 (1), 121-146.

Katz, L.F., Autor, D.H., 1999. Changes in the Wage Structure and Earnings Inequality. In: Ashenfelter, O.C., Card, D. (Eds.), Handbook of Labor Economics. Vol. 3, Part A.. Elsevier, Amsterdam, pp. 1463-1555.

Lazear, E.P., 1979. Why is there mandatory retirement? J. Polit. Econ. 87 (6), 1261-1284.

Lee, K.H., Mauer, D.C., Xu, E.Q., 2018. Human capital relatedness and mergers and acquisitions. J. Financ. Econ. 129 (1), 111-135.

Lichtenberg, F., Siegel, D., 1990. The effects of leveraged buyouts on productivity and related aspects of firm behavior. J. Financ. Econ. 27 (1), 165-194.

Lindbeck, A., Snower, D.J., 1986. Wage setting, unemployment, and insider-outsider relations. Am. Econ. Rev. 76 (2), 235-239.

Lindbeck, A., Snower, D.J., 1988. Cooperation, harassment, and involuntary unemployment: an insider-outsider approach. Am. Econ. Rev. 78 (1), $167-188$.

Matsa, D.A., 2010. Capital structure as a strategic variable: evidence from collective bargaining. J. Finance 65 (3), 1197-1232.

Mishel, L., Schmitt, J., Shierholz, H., 2013. Assessing the Job Polarization Explanation of Growing Wage Inequality.. University of California, Berkeley, CA. Unpublished working paper.

Olsson, M., Tåg, J., 2017. Private equity, layoffs, and job polarization. J. Labor Econ. 35 (3), 697-754

Pence, K.M., 2006. The role of wealth transformations: an application to estimating the effect of tax incentives on saving. B.E. J. Econ. Anal. Policy 5 (1), 1-23.

Petersen, M.A., 2009. Estimating standard errors in finance panel data sets: comparing approaches. Rev. Financ. Stud. 22 (1), 435-480.

Poletaev, M., Robinson, C., 2008. Human capital specificity: evidence from the dictionary of occupational titles and displaced worker surveys, 1984-2000. J. Labor Econ. 26 (3), 387-420.

Ray, D., 2002. The time structure of self-enforcing agreements. Econometrica 70 (2), 547-582.

Rosett, J.G., 1990. Do union wealth concessions explain takeover premiums? The evidence on contract wages. J. Financ. Econ. 27 (1), 263-282.

Schild, C., 2016. Linking "Orbis" Company Data with Establishment Data from the German Federal Employment Agency. German Record Linkage Center, Nuremberg, Germany. Unpublished working paper wpgrlc-2016-02

Schmucker, A., Seth, S., Ludsteck, J., Eberle, J., Ganzer, A., 2016. Establishment history panel 1975-2014. FDZ Datenreport, 03/2016 (en), Nuremberg, Germany.

Schäffler, J., 2014. ReLOC linkage: a new method for linking firm-level 
data with the establishment-level data of the IAB. FDZ-Methodenreport 05/2014, Nuremberg, Germany.

Shleifer, A., Summers, L.H., 1988. Breach of trust in hostile takeovers. In: Auerbach, A.J. (Ed.), Corporate Takeovers: Causes and Consequences. University of Chicago Press, Chicago, IL, pp. 33-56.

Simintzi, E., Vig, V., Volpin, P.F., 2014. Labor protection and leverage. Rev. Financ. Stud. 28, 561-591.

Tate, G.A., Yang, L., 2016. The human factor in acquisitions: cross-industry labor mobility and corporate diversification. US Census Bureau Center for Economic Studies Paper CES-WP-15-31.. US Government Printing Office, Washington, DC.
Weisberg, J., 2012. The pain in Bain. Slate, July 17

Wong, G., 2007. Private equity and the jobs cut myth. CNNMoney.com, May 2. http://money.cnn.com/2007/05/02/markets/pe_jobs/index.htm. Wright, M. Bacon, N., Amess, K., 2009. The impact of private equity and buyouts on employment, remuneration, and other HRM practices. J. Ind. Relat. 51 (4), 501-515.

Wright, M., Thompson, S., Robbie, K., 1992. Venture capital and management-led leveraged buy-outs: a European perspective. J. Bus. Ventur. 7 (1), 47-71. 